-

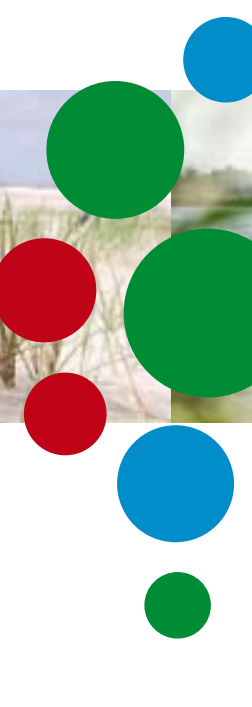

Knowledge

A State of the Art of Governance Literature on Adaptation to Climate Change:

\title{
Towards a Research Agenda
}




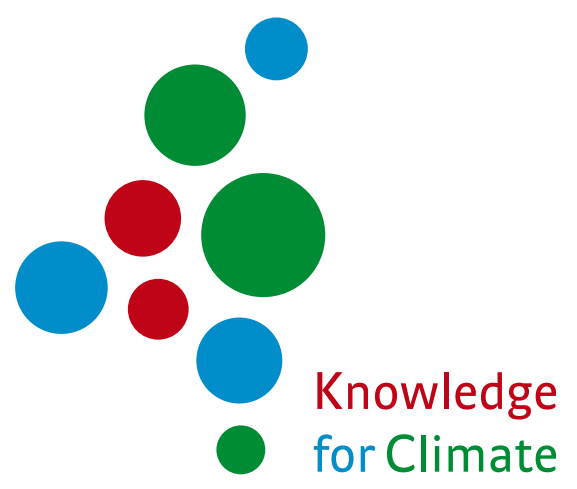

\title{
A State of the Art of Governance Literature on Adaptation to Climate Change:
}

\section{Towards a Research Agenda}

\author{
Authors \\ Drs. Kim van Nieuwaal ${ }^{1)}$ \\ Prof.dr. Peter Driessen ${ }^{1)}$ \\ Prof.dr. Tejo Spit ${ }^{2)}$ \\ Prof.dr. Catrien Termeer ${ }^{3)}$
}




\section{Copyright @ 2009}

National Research Programme Knowledge for Climate/Nationaal Onderzoekprogramma Kennis voor Klimaat (KvK) All rights reserved. Nothing in this publication may be copied, stored in automated databases or published without prior written consent of the National Research Programme Knowledge for Climate / Nationaal Onderzoekprogramma Kennis voor Klimaat. Pursuant to Article 15 a of the Dutch Law on authorship, sections of this publication may be quoted on the understanding that a clear reference is made to this publication.

\section{Liability}

The National Research Programme Knowledge for Climate and the authors of this publication have exercised due caution in preparing this publication. However, it can not be excluded that this publication may contain errors or is incomplete. Any use of the content of this publication is for the own responsibility of the user. The Foundation Knowledge for Climate (Stichting Kennis voor Klimaat), its organisation members, the authors of this publication and their organisations may not be held liable for any damages resulting from the use of this publication. 


\section{Contents}

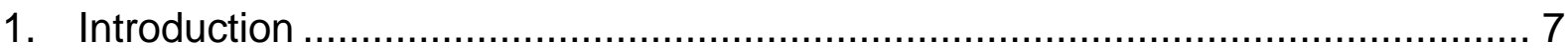

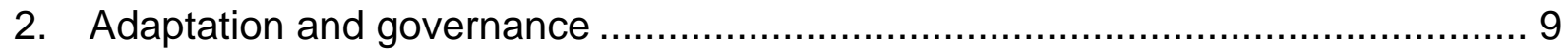

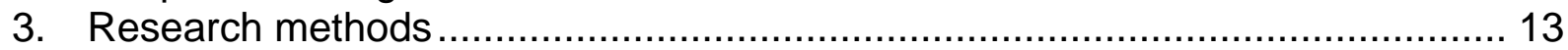

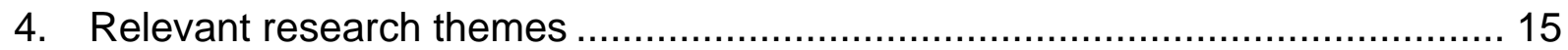

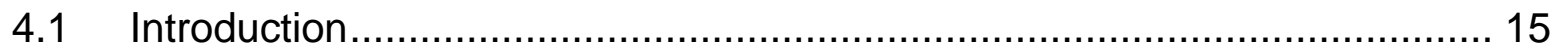

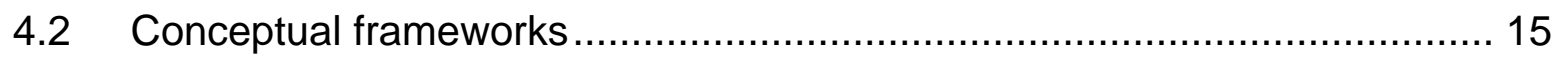

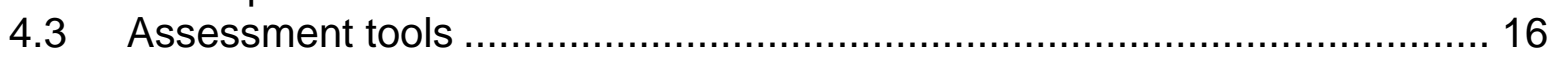

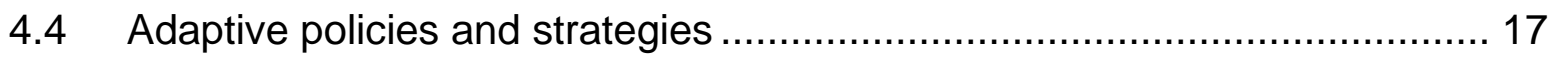

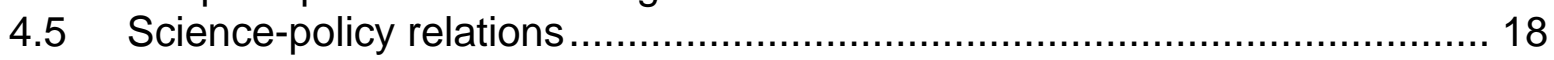

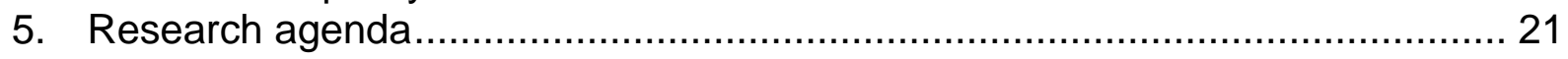

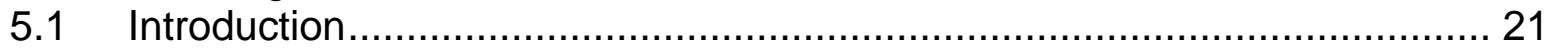

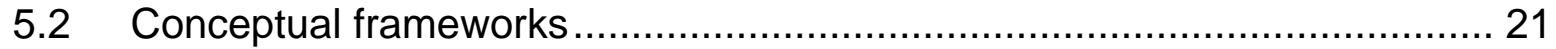

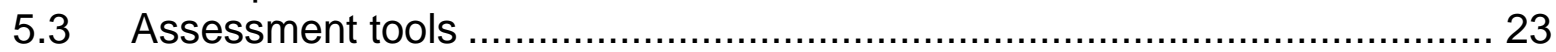

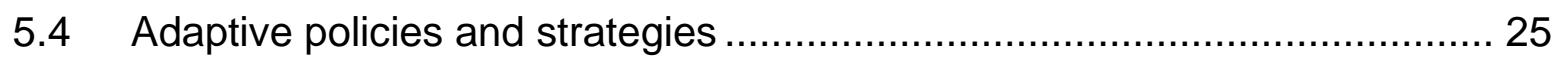

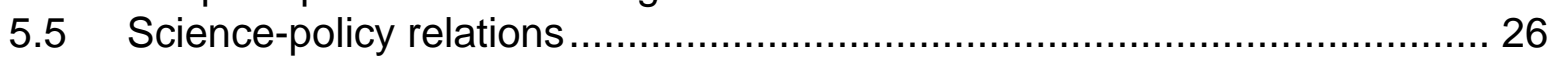

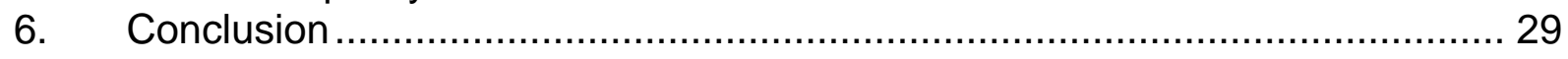

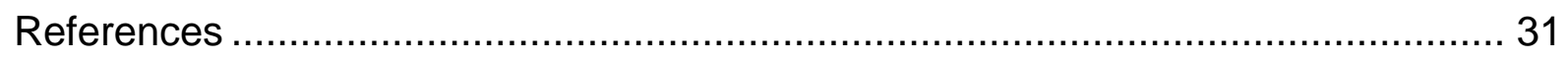

Appendix 1A: Journals Environmental Studies, ISI Ranking on impact factor ......... 39 Appendix 1B: Journals Planning and Development, ISI ranking on impact factor .... 41 Appendix 1C: Journals Public Administration, ISI ranking on impact factor............ 43 
?ำ? 


\section{Introduction}

Awareness of climate change has increased and, as a result, more and more mitigation strategies are being developed and implemented. Notwithstanding these efforts to reduce $\mathrm{CO}_{2}$ emissions, the effects of global warming cannot be stopped - let alone reversed - instantly. For instance, even an immediate world-wide cessation of $\mathrm{CO}_{2}$ emissions would not eradicate the need for protecting societies from the unfolding processes of climate change (Wilbanks et al., 2003; Stehr \& Von Storch, 2005; Tol, 2005; Mata \& Budhooram, 2007). In addition, regardless of the future dynamics of climate change, the New Orleans flood of 2005 has indicated how even a relatively prosperous region in the world can currently be vulnerable to such large-scale disasters. The threat to assailable, yet poorer areas such as Bangladesh, is even more pregnant (e.g. Ribot et al., 1996; Adger et al., 2001; Smit \& Pilifosova, 2001; Downing, 2003; Tompkins \& Adger, 2004). Consequently, adaptation strategies are high on the political and societal agenda. Nevertheless, research by Breeman \& Timmermans (2008) has revealed that interest in environmental issues comes and goes, depending on the state of the economy, unexpected incidents, and the competition with other issues in the political arena. In other words, the extent to which climate adaptation will hold its position within the higher regions of the political agenda remains to be seen.

Adaptation strategies focus on anticipating the impacts of climate change in three terms: moderating potential damage, coping with the consequences or taking advantage of opportunities. From that perspective, a major task lies ahead to make certain parts of the world climate proof. However, developing and implementing adaptation options is by no means an easy task due to all kinds of institutional and social complexities.

Adaptation to climate change is a complex assignment for several reasons. First of all, it is a matter of uncertainty and ambiguity. The knowledge base for defining the problem and possible solutions is insufficient and disputed: what exactly is the problem, and what specific action should be undertaken? In addition, confusion results from multiple interpretations and frame differences. The nature of the problem and the human role in it are continuously being debated, either from a normative or a scientific angle. Processes of autonomous change that are at stake contribute to the uncertainty and unpredictability. At the same time, however, causes of climate change can also lie in social phenomena, such as the depletion of natural resources.

Investments in adaptation are not only a matter of mere infrastructural adjustments, such as building dikes, they also involve general issues like ecology, agriculture, urban and regional planning, nature preservation and energy supply. Climate change, being a global phenomenon and requiring collective and international intervention, implies scaling problems considering that it is particularly the national, regional and local levels that are affected in practice, either by implementing adaptation measures or by the consequences of the lack thereof. Threats and opportunities deriving from climate change differ from place to place. Climate adaptation takes place in a multi-actor setting and is blurring the traditional boundaries between countries, between administrative scales, and between the public and the private sector. At these levels, actors bring with them a variety of values, interests, resources and perspectives. The problems cut across the jurisdictions and routines of organisations and sectors and are thereby blurring traditional boundaries. The multifaceted problem of climate change could thus provoke contrasting policy impulses when different ministerial echelons are involved.

Moreover, the social and ecological dynamic processes require long-term horizons, demanding the specific commitment of tax payers, politicians and scientists. Long-term investments seem to be needed but at the same time today's solution could become tomorrow's problem. Despite the panoramic predictive perspectives, adaptation is also a matter of the here and now, hence demanding constant temporal scaling of those involved. Nonetheless, people expect governments to choose the appropriate adaptation strategies to safeguard them from flood, draught, heat and other effects of climate change. As a consequence, climate adaptation requires a constant alternation of short-term and long-term anticipation.

In conclusion, it could thus be stated that adaptation is not only, or particularly, a technical issue, but that it can be characterised as a complex social interaction process and that it should be studied as such. Only then can adaptation to climate change also be regarded as a window of opportunities. 
Dealing with climate adaptation not only demands a rethink of how we arrange our social-ecological or socio-technical systems but also how we govern them.

This report provides a state-of-the-art overview of governance literature on adaptation strategies. What has recent research taught us on adaptation from the perspective of governance and to what research agenda does this lead?

This report is structured as followed. Firstly, it will be argued why adaptation is a matter of governance. Secondly, the research methods for the literature study will be outlined. Thirdly, the results of the literature study will portray the findings in terms of the themes and foci with, respectively,

environmental studies, spatial planning and development studies, and public administration studies. Finally, a comparative analysis of these findings will lead to a research agenda for future research on governance of adaptation. 


\section{Adaptation and governance}

When being interviewed for the Dutch eight-o-clock news on May 30th 2008, the Minister of Internal Affairs declared that government might not be able to rescue everybody in the case of a disaster such as a flood. Apparently, people also have their own responsibilities and what can be expected from government has its limitations. This statement has two particular and notable aspects to it in the light of governance of adaptation. Firstly, it was an obvious trigger to establish changes concerning the perception of the public with regard to the responsibility and capability of government in the case of natural disasters. Secondly, it focused on one particular momentum on the disaster timeline, separating the process of preventing disasters from that of overcoming them. The relevance of perception and temporality for adaptation were thus highlighted. In addition, the general question remains: what then is the government's role in this respect.

The concept of 'governance'

The Minister's statement is in alignment with the tendency of government to position itself less hierarchically within society (Kettl, 2002; Salamon \& Elliott, 2002; Frederickson \& Smith, 2003, Hill \& Lynn, 2005). New public management prominents Osborne \& Gaebler (1992), for instance, have argued that governments should do the steering rather than the rowing. In other words, the role of such catalytic governments is to coordinate and guard crucial processes in society. In addition, administrative relationships with the outside world are thus less hierarchical but more of a cooperative kind.

It fits in with the popular narrative of a proclaimed shift from 'government' to 'governance'. During the last decades it has become common in the scientific field of public management and political science to promote a shift from hierarchical and well-institutionalised forms of government towards less formalised forms of governance (Hanf \& Scharpf, 1978; Ostrom, 1990; Marin \& Mayntz, 1991; Rhodes 1997; Glasbergen, 1998; Pierre 2000; Blatter 2003; Klijn 2005; Arts \& Leroy 2006). These narratives have not only become very popular in analysing complex interactions around policy-making, but also in thinking up and proposing alternative strategies for policy-making, such as network management, interactive governance, collaboration, deliberative policy-making, inclusive management or partnerships, among other things (Kickert et al., 1997; Glasbergen \& Driessen, 2005; Edelenbos 2005; Mandell \& Steelman 2003; Hajer \& Wagenaar 2003; Fischer 2003; Feldman \& Khademian 2007; Diamond \& Liddle 2005; Glasbergen, Biermann \& Mol, 2007). In general, these policy strategies aim at more horizontal interactions between government, citizens, firms and non-governmental organisations, and are regarded as a way to decrease the perceived gap between government and society, to enrich the policy proposals and to increase the chance of successful policy implementation (Termeer 2009). Some authors even speak of a 'hollow state' (Frederickson \& Frederickson, 2006; Milward, 1994; Milward \& Provan, 1993; Salamon, 1981) as a consequence of governments moving away from bureaucracy and direct administration. A less extreme positioning is the perspective of contemporary governments involved in both horizontal and vertical relationships or as governance in the shadow of hierarchy (Sharpf, 1997).

However, the concept of governance is surrounded by a certain amount of confusion. First and foremost, some authors seem to reserve the governance definition for networks only, and exclude other steering mechanisms, such as hierarchy, community or the market (Rhodes, 1997). Other authors in public administration and public policy define governance as the setting, application, and enforcement of rules guiding the pursuance of public goods, whether these rules are developed and enforced by markets, hierarchies, or networks (Kjaer, 2004).

Secondly, confusion has much to do with the fact that the governance concept has been used both in the sense of structure and process (Pierre \& Peters, 2000). Governance as structure refers to an institutional design. It relates to the patterns and mechanisms in which social order is generated and reproduced (Voss, 2007). Governance as process refers to managing networks (Rhodes, 1996: 658). In this understanding, governance involves agency; not the intentional acts of single individuals but the process that results from the involvement of many states or societal agents (Kjaer, 2004). Kooiman (1993) and Mayntz (1993) distinguish between 'governing' and 'governance' by defining governing as "all those activities of social, political and administrative actors that can be seen as purposeful efforts to guide, steer, control, or manage (sectors or facets of) societies", and governance as "the patterns that emerge from governing activities of social, political and administrative actors". Governing, then, 
presupposes a subject (an actor) while governance is the results of the actions taken, a mode of social coordination.

Finally, some scholars reserve the concept of governance to stress the importance of some kind of coordination concerning global or transboundary problems. It is about governance without government. In the field of international relations, increasing globalisation has raised a need for global governance in many arenas such as trade regulation, the environment, and conflict resolution (Held et al., 1999; Held \& McGrew, 2000).

This paper elaborates on a broad definition of governance. It includes both network, market and hierarchy; it includes both structure and process and it stresses the multilevel character. Despite its obvious connotation, governance is thus not primarily a matter of government. This approach is very much in line with the statement made by the Dutch minister concerning the role of government in the case of a flood, as mentioned at the start of this section. In other words, the minister thus labelled adaptation as an issue of governance. Apparently, government has its share in this assignment, yet action is also required from other societal actors (cf. Lemos \& Agrawal, 2006).

Now that it has been argued why adaptation can be considered a matter of governance, it has to be noted that the subsequent approach of governance in this report also implies a certain approach to spatial planning. Consequently, for our study, spatial planning is regarded as a specification of governance, focusing on the spatial dimension involved.

The putting into practice of governance implies that a wide variety of actors become involved in the issue of climate adaptation. The horizontally expanding network of stakeholders, however, hampers processes of systematic articulation of research questions. Governance research has seen a constant shift of various emphases and foci. For instance, where today's governance literature highlights innovative arrangements, two decades ago it was the policy instruments and implementation problems that got most attention (Leroy \& Nelissen, 2002). Other common topics that have been covered by governance literature are those that deal with institutions, organisation and management, policy and decision making. The relevance of acknowledging this kaleidoscopic diversity within governance research for our study is twofold. Firstly, it gives insight into the body of literature needed to flesh out our notion of governance of adaptation. Secondly, it sustains the assumption that more integrative and holistic research and research questions are needed to tackle the complex assignment of climate adaptation as it has been postulated in the above.

\section{Adaptation and the Dutch case}

'An Inconvenient Truth' designates the Netherlands as one of the first countries expected to sink into the sea in the case of a further rise in sea level. Such a scenario not only assumes an ongoing process of sea level rise, it also premises insufficient adaptation. The fact that large parts of the country are below sea level does indeed designate the Netherlands as vulnerable to climatic factors. KNMI (the Royal Dutch Meteorological Institute) predicts that Western Europe, including the Netherlands, will face processes of climate change that will ensue much more rapidly than elsewhere in the world (KNMI, 2008). In addition, the big rivers bringing water from all over Europe to Dutch territory only adds to that assailable geographic situation. Dutch R\&D institute TNO has designated floods to have the "largest damaging effects on the western parts of the Netherlands, possibly up to tens of billions of euros." (TNO, 2008: 10). However, set against that is the long tradition that the country has in fighting the water. The dikes, the 'Deltaworks', reclaimed land such as the Province of Flevoland or parts of the Port of Rotterdam are exponents of the Dutch curriculum on fighting the water, either from an offensive or defensive approach.

Dutch government has acknowledged the urgency of adaptation in the light of climatic changes ${ }^{1)}$. Currently, for instance, the research programmes 'Climate changes spatial planning' and 'Knowledge for Climate' are coordinating scientific research aimed at climate proofing the Netherlands ${ }^{2)}$. Adaptation is thus a national assignment in which government, research institutes and businesses participate. In other words, adaptation in the Dutch case is a matter of governance. As a consequence, this complex assignment has many aspects to it, amongst which are the environmental, technical,

\footnotetext{
${ }^{1)}$ The motion, put forward by Senator Lemstra, on March 21, 2005, led national government to set up the programme Adaptation Spatial Planning and Climate (Adaptatie Ruimte en Klimaat), running from 2006 to 2014.

${ }^{2)}$ www.klimaatvoorruimte.nl and www.knowledgeforclimate.org
} 
social, spatial, administrative, commercial, scientific, legal and psychological aspects. In order to treat the issue of adaptation in terms of governance and from a multidisciplinary approach, this research will entail an assessment of social sciences literature. As it will be argued in the following, three domains have been designated as potential sources of literature relevant to a study on climate change from a governance perspective: environmental studies, planning and development, and public administration.

Three goals of governance research

Governance research can serve three goals that are relevant for our study. Firstly, governance research can be descriptive, answering questions such as "what is the content of the policy?", "what does it imply in practice?", "who is involved?", "what are the outcomes?", etcetera. Secondly, governance research can serve an analytical purpose by supplying historical, institutional and theoretical explanations for questions why things go the way they go, plus what works best and why. Verschuren \& Doorewaard (1999: 78), for instance, mention in this respect three forms of relevant knowledge: explanatory knowledge, predictive knowledge and evaluative knowledge. Thirdly, governance research can be normative, prescribing which policy should be implemented and how, based on theoretical considerations or practical experience. All three approaches within governance research are taken into account in this study. 
?ำ? 


\section{Research methods}

A state-of-the-art assessment is crucial to answer the research question underlying this study. Now that we have designated adaptation to climate change as an issue of governance, what insights does the social sciences literature provide in that respect? Only when the themes and foci within that body of literature have been detected can a research agenda for adaptation strategies be established. Governance of adaptation implies the obvious connection of administration and ecology. Three scholarly domains have thus been selected from which relevant literature has been retrieved: (1) environmental studies, (2) planning \& development and (3) public administration (see figure 1). These domains match the categories used within the ISI Web of Knowledge database. This database hosted by Thomson Scientific contains 13,000 scientific journals and serves as a major international research platform. The three domains are expected to encompass the lion's share of research on governance of adaptation. For each of the domains the ISI journals have been ranked by impact score for the year 2007, resulting in three lists with high-impact journals at the top. Subsequently, all journals have been searched for '[adaptation] and [climate change] and [governance]'. In addition, all journals have also been searched for only '[adaptation] and [climate change]'. The reason for this is that a query of these two key words delivered more relevant articles for our research than a query that included '[governance]'.

The assessment through the ISI domains, and going back to the year 2000, ultimately suffers from two obvious drawbacks: non-ISI sources are not assessed, and sources older than 8 years are initially neglected. A fourth domain of 'additional sources' was thus created in order to include miscellaneous sources, such as non-ISI journals and books. This category also included the assessed Dutch journals, which were mostly found within the domains of 'planning and development' and 'public administration'.

For all three domains, the articles and additional sources have been studied to try and find themes and foci with regard to governance of adaptation. These findings will be discussed in the following sections. Subsequently, these analyses will be compared in order to establish a common core of themes and foci and to demarcate the lacunas as a basis for a research agenda. 


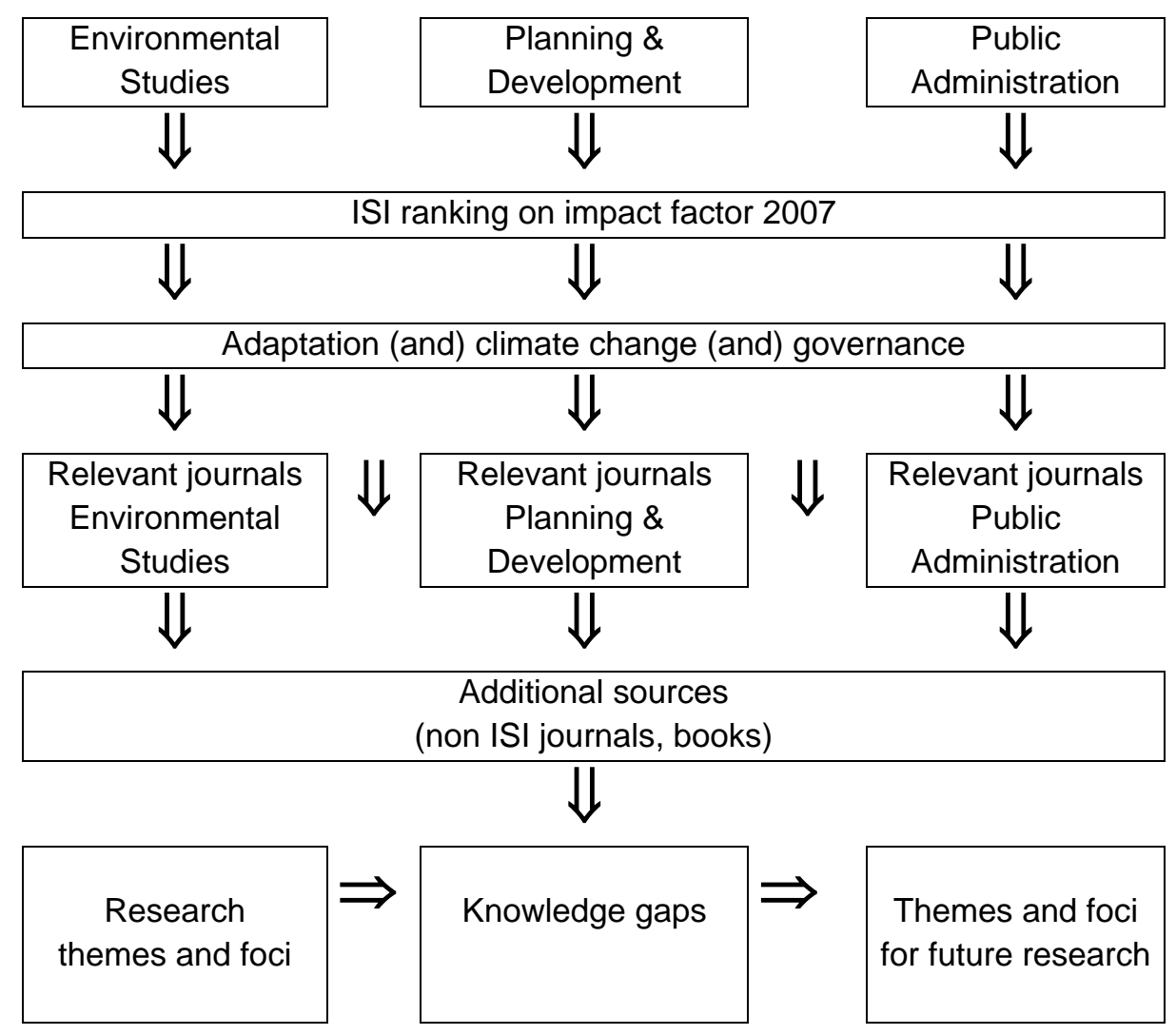

\section{Figure 1: Research steps}

The search for relevant articles also implied a list of relevant journals within each of the domains. It has to be noted that some journals appeared on two - hence not mutually exclusive - lists. Not only do some journals have a higher impact factor, which is only one contemporary academic criterion, some articles are of course more significant for our research than others. In addition, not all relevant journals are listed on the ISI ranking. As a consequence, additional journals have been taken into account as well. The snowball method pays off when reference lists are checked for additional sources. Occasionally, other sources such as books were also taken into account. One particular additional pool of sources was that of Dutch non-ISI, hence non-English, journals. The current affiliation of the researchers and the intention to incorporate this study into the current national research programme 'Knowledge for Climate' were the rationale behind the decision for this additional exercise. The structured search went back to the year 2000. Older articles and sources, if relevant, were expected to come into the picture via the mentioned snowball method.

The assessment of the literature within the three domains, including the additional sources, led to a body of literature with a potential for our study on governance of adaptation. A modest quantitative analysis reveals that the 'governance of adaptation' is hardly present in the domain of 'public administration'. The same applies for 'planning and development', but to a lesser extent. Governance of adaptation thus promised to be a specialized field, mainly within the domain of 'environmental studies'. Until now, the most important journals seem to be: Climate Policy, Global Environmental Change, Annual Review of Environment and Resources and Environment and Urbanization.

A qualitative analysis led to the demarcation of four relevant themes, each encompassing a set of specific topics. These findings, in turn, were used as the basis for composing a research agenda for governance of adaptation by pinpointing the gaps and knowledge lacunas within the current literature. The preliminary findings were subjected to an expert meeting with representatives of knowledge institutes in the Netherlands and the subsequent insights were incorporated into the final version of this report. 


\section{Relevant research themes}

\subsection{Introduction}

For this study, four major themes relevant to governance of adaptation have been demarcated. Together, they encompass the entire range of the literature on the topic. In addition, there appears to be a certain logic in this particular demarcation as the themes cannot only be treated separately, analytically, their interconnection makes sense also. Hence, not surprisingly, literature on governance of adaptation generally touches upon more than just a single topic. Ideally, as it is argued here, the study of governance of adaptation as a whole should incorporate all four themes, including additional attention to the aspect of interconnectedness. Thus, governance of adaptation requires insights into and application of - the various conceptual frameworks, assessment tools, actual policies and strategies, and the science policy interface if actual adaptation strategies are meant for short-term and long-term efficiency and effectiveness across geographical and administrative scales. In this chapter, the state of the art for each of the research themes will be outlined. Not surprisingly, the main findings will find their way into the research agenda subsequently.

\subsection{Conceptual frameworks}

Many studies in the literature on governance of climate adaptation were conducted dealing with new frameworks and concepts of modes of governance or modes of management. These concepts carry names such as adaptive governance (Folke et al., 2005; Brunner et al., 2005); resilience management (Walker et al., 2002); adaptive management (Arvai et al., 2006; Pahl-Wostl, 2007); adaptive comanagement (e.g. Ruitenbeek \& Cartier, 2001; Olsson et al., 2004; Kalibo \& Medley, 2007; Armitage et al., 2008; Hahn et al., 2006); adaptive collaborative management (Kalibo \& Medley, 2007); environmental governance (Lemos \& Agrawal, 2006); and earth system governance (Biermann, 2007). It is safe to state that this literature has an ambitious goal to converge the inherent complexity and unpredictability of ecosystem dynamics into new governance or management concepts.

Although these concepts differ, they all share many characteristics (see also Dewulf et al., 2008). Adaptive management was originally developed as a management approach for ecological systems and has evolved into a broader research field of the adaptive governance of social-ecological systems (Folke et al., 2005). The term of socio-ecological systems has its basis in ecological and earth science and is used to emphasize the integrated concept of humans in nature and to stress that the delineation between social and ecological systems is artificial and arbitrary (Folke et al., 2005:443). Because socio-ecological systems are studied as complex adaptive systems, the notion of adaptability, in order to increase resilience and decrease vulnerability, is a very important one (Carpenter et al., 2001). Systems show high adaptability when the actors have the capacity to reorganise the system within desired states in response to changing conditions and disturbance events (Folke et al., 2005: 444).

Drawing on these socio-ecological systems characteristics, adaptive management focuses on strategies to cope with a world that changes continuously in unpredictable directions (Dewulf et al., 2008). While these changes can be gradual, abrupt or turbulent changes are tending to become more prominent. In episodes of turbulent change, available experience and expertise often proves to be incomplete, the consequences of action are unclear and the future of the system is uncertain. Vulnerable ecosystems, for example, can rapidly shift into unwelcome states and stop providing ecosystem services to society. Similarly, socio-ecological systems can loose their resilience to keep fulfilling basic functions in conditions of change or disturbance.

Attempts to manage or steer have to take into account uncertainties and both gradual and abrupt changes. Therefore, learning plays a central role in adaptive management as a way of keeping knowledge up to date with continuously changing conditions. It proceeds on experiments by simultaneously implementing varied management treatments and then comparing the results (Berkhout et al., 2004; Brunner, 2005; Folke et al., 2002; Folke et al., 2005; Johnson, 1999; PahlWostl, 2006; Raadgever et al., 2008). It goes beyond management by trial and error as it is also structured and theory-driven, such that new knowledge can be incorporated systematically into future treatments (Arvai et al., 2006: 218) By using the concept of social learning, Pahl-Wost and others stress the social context of learning. Social learning can be defined as learning through participatory systems such as groups, networks, organisations and communities, in conditions which are new, unexpected, uncertain, conflictive and hard to predict (Wildemeersch et al., 1998). Combining different types of knowledge (scientific, professional, experiential, indigenous, etc.) and interactions across 
scales is an important feature of this learning (e.g. Berkhout et al., 2006; Hutter, 2007; Armitage et al., 2008). To emphasise the importance of involving local communities in resource conversation Kalibo and Medley (2007) talk about adaptive collaborative management.

Besides social learning, literature also devotes attention to the concepts of leadership, transformations, innovation, organisational learning, social capital, trust, knowledge, resilience, self organising, monitoring, social memory, actor groups, etcetera. Some authors, for example Folke et al. (2005), try to integrate all these concepts into one theoretical framework. Although the different notions are all very important and interesting, the total picture becomes a little confusing and abstract.

So far, we have discussed adaptive management. What about adaptive governance? We understand the added value of the concept of adaptive governance as the governance context that enables, or at least legitimises, adaptive management strategies. Put differently, authors plead for a institutional fit between adaptive management and the governance system. Biermann (2007) even talks about adaptive states as states able to adapt internally and externally to large-scale transformations of its natural environment. In the literature on governance of adaptation, much attention is devoted to the characteristics of such states. All authors of the articles reviewed stress the importance of multilevel systems, cross-scale interactions and networks that connect individuals, organisations, agencies, and institutions at multiple organisational levels (e.g. Adger, 2001; Adger et al., 2005; Kok \& De Coninck, 2007; Olsson et al., 2006). In order to adapt to new situations the governance system also requires flexible institutional arrangements that encourage reflection and innovative responses and some redundancy, in the form of polycentric institutional arrangements, with nested quasi-autonomous decision-making units operating at multiple scales (Folke et al. 2005). Also, conditions for selforganisation, created through enabling legislation and policies, can increase the ability to adapt (Brunner, 2005; Folke et al., 2002; Pahl-Wostl, 2006). Special attention is given to the role of leaders who are able to provide key functions for adaptive governance such as, "building trust, making sense, managing conflict, linking actors, initiating partnership among actor groups, compiling and generating knowledge, and mobilizing broad support for change" (Folke et al., 2005: 451).

\subsection{Assessment tools}

Part of the literature on governance of adaptation deals with assessment tools. Central within this theme is the uncertainty involved in adaptation and climate change. The agency that adaptation requires must take into account future phenomena, either inherent to ecological processes, social processes, or interaction of the two. The better the estimates, the better the support for actual decisions, as is often assumed. The quality of the estimates partly depends on the quality of the current measurements. Thus, governance of adaptation literature is also occupied with the question of how relevant trends and phenomena can best be measured.

Adaptation is looking ahead. And ahead are risks. The likeliness, qualifications and consequences of these risks lie at the core of deliberations on adaptation strategies. Risks imply uncertainty. Parson et al. (2003: 34) state that "pervasive continuing uncertainty is sufficiently likely in climatic, ecological, and socio-economic domains that assessment must embrace uncertainty". The scope of assessments relevant for governance of adaptation, however, is vast. Assessments can involve, for instance, vulnerability (e.g. Brooks et al., 2005; Berry et al., 2006; Erikson \& Kelly, 2007; Al-Jeneid et al., 2008), costs and benefits (e.g. Callaway, 2004), cause-effect frameworks (Barker, 2003), impact (e.g. Gallart \& Llorens, 2003), resilience (e.g. Barnett, 2001) and robustness (e.g. Dessai \& Hulme, 2007). A recent trend has been to incorporate such indicators into scenario building, like the IPCC has been doing in its reports. Dessai et al. (2005) argue that the challenge in this respect will be to develop more custom-made scenarios that do justice to specific contextual factors such as scale, capacity, assessment approach, and type of adaptation. Similarly, Pyke et al. (2007) argue that "Decision support must be not only technically suitable to the problem at hand (e.g. the right data and analytical tools) but also be feasible and acceptable to stakeholders (e.g. applied to the right decision made by the approximate organization)" (Pyke et al., 2007: 617). Parson et al. (2003) stress the long-term agenda needed for such assessment models. Literature on governance of adaptation, as studied for this research, has proven to be a welcoming arena for these claims and arguments. At the same time, however, a vast amount of research on assessment tools and their practical implications is expected to remain somewhat disconnected from the governance literature, particularly when dealing with more technical and applied tools. For this study, this body of literature has thus remained relatively underemphasized. 
Uncertainty, that assessment tools try to repress, does not only lie at the core of this particular theme, it features a key character of the issue of climate adaptation. In fact, uncertainty is a conditio sine qua non. In other words, if it were not for uncertainty, there would not be such a problem to be solved. Taking this argument further and taking into account the previous contention that uncertainty encompasses both social and ecological dynamics, raises the question which uncertainties constitute the sufficient conditions of the problem. Despite the fact that governance of adaptation has been designated as a social phenomenon in this study, it has to be acknowledged that the crucial trigger for the adaptation assignment is the incomprehension of ecological phenomena, rather than that of human behaviour. At the same time however, it is this immense gap to be bridged by natural sciences that legitimises the quest for governance tools, because it is widely acknowledged that the uncertainty involved in climate change will remain, though immediate and significant action is required. Governance literature is thus treated with an extra amount of uncertainty when dealing with climate adaptation. We have seen the reflections of that in the previous theme and we will see people struggling with uncertainty in the following theme, dealing with adaptation in practice. Many studies apply assessment tools to particular cases, often location-specific. The final theme, dealing with science-policy relationships will, hardly surprisingly, focus on the 'piece de resistance', where science trying to tame uncertainty is entering the arena where actual decisions are being made, uncertainty or not.

Departing from there, it makes both policymakers and scientists wonder to what extent uncertainty can be diminished and what the aspirations and expectations in that respect should be. Dessai \& Hulme (2004) even wonder if climate adaptation needs probabilities. The authors distinguish between biophysical vulnerability approaches on the one hand and social vulnerability approaches on the other, which is in line with the earlier mentioned distinction between social and ecological dynamics. The authors argue that this particular coming together of two distinct approaches should be accompanied with combining scenario and probability-based scenarios. Rather than aiming to fully predict and grasp relevant dynamics, policy making should cope (see also: Adger, 1999; Barnett, 2001; Burton et al., 2002; Clark \& Pulwarty, 2003) with an inherent uncertainty when trying to enhance resilience.

Berkhout et al. (2002) have also emphasized the value of human reflections on the implications of their behaviour for making adjustments. The driver for such argumentation, and attributed behaviour, seems to be the risk-avoiding nature of human beings. The notion of the risk-avoiding society (Beck, 1992) can thus also be applied to the issue of climate adaptation.

\subsection{Adaptive policies and strategies}

Literature on governance of adaptation also incorporates research with adaptive policies and strategies as the object of study (i.e. Bulkeley, 2006; Swart et al, 2009). The complexity involved in the governance of adaptation leaves room for a wide variety of empirical cases, either found within the social reality and/or the ecological reality. The general question that such studies intend to answer is what adaptation looks like in the empirical world. Often, the object of study is geographically demarcated, focusing on for instance Pacific Islands (Barnett, 2001), Norway (Lindseth, 2005), Canada (Wellstead and Stedman, 2007), the UK (Wilson, 2006; McKenzie Hedger et al., 2006), Eastern Ontario (Crabbé and Robin, 2006), East of England (Dessai and Hulme, 2007), Christchurch Bay (Few et al., 2007), Kristianstad (Hahn et al., 2006), etcetera. Some of the studies are directed towards administrative levels, from the local to the global scale (Berkhout, 2005; Burton, 2007) or specific to developing countries (i.e. Jerneck and Olsson 2008; Agrawala and Van Aalst, 2008; Leary et al. 2008; O'Brien et al., 2008; Huq et al., 2004). A worthwhile comparative study on adaptation strategies in different European countries was published by Swart et al. (2009).

Most of the literature, however, is issue related. Flooding is such a major issue (Bronstert and Kundzewicz, 2006; Calder \& Aylward, 2006; Crabbé and Robin, 2006; Dalhuisen et al., 2003; Dessai and Hulme, 2007; Falconer and Harpin, 2005; Gallart and Llorens, 2003; Hay and Mimura, 2005 etc.) Other, less prominent issues are agriculture and forestry.

As far as we can see, three important topics in the literature on adaptive policies can be identified, which in themselves cover another large variety of issues: literature on environmental issues, urban issues and literature on adaptive strategies in regions (including the interaction between layers of government). Each of these categories have their own characteristics and will therefore be discussed separately. 
Environmental issues

Adaptive policies can be seen in many studies covering environmental issues. Some are closely related to water issues (not flooding), such as waste water, river management, salination, drinking water, ground water levels, etc. Others deal with ecological quality and preservation areas. The relation with climate change is sometime direct (cause-effect studies), but mostly indirect as changes in the climate is only part of the problem. One thing, however, stands out: most of the contributions are structured from certain scientific perspectives which are dominated by a normative view on the problem (preservation is good, all change is a threat to the environment, etc.). Certainly, in such complex research this can be considered a rather one-sided view.

\section{Urban issues}

The variety under this heading is immense. However most of the publications address climate change especially as a new sense of urgency to tackle urban problems, than that it generates specific adaptation strategies in itself. In other words, climate change has - until now - neither much impact on the way urban planning addresses spatial challenges, nor on the urban planning agenda. The overview, as presented in Figure 1, shows relatively few articles on this subject, considering the number of journals. However, this is slowly changing. Specific subjects related to climate change, such as urban heat islands, water in cities etc. are getting more attention.

However, the conclusion at the moment must be that -until now- the literature on urban issues is little affected by climate change. Only the sense of urgency remains.

\section{Adaptive strategies in regions}

A major topic in literature is on adaptive strategies in regions. These studies mostly cover very theoretical papers, occasionally illustrated with one or more case studies. The case studies can cover either a specific area or a specific topic. The most striking characteristics of these papers are the highly theoretical approaches. Although the number of papers is relatively impressive (e.g. compared to urban issues), it only sheds some light on the theoretical side of adaptive strategies. Therefore, many other questions remain unaddressed. One relevant and interesting aspect, however, is the complex interaction between layers of government (including the other actors) (see for instance: Mickwitz et al, 2009). Regime theory is also often mentioned.

What remains are some general themes which play some kind of role in all topics. The issue of risk and risk reduction is such a theme. Sometimes it is observed as part of a problem (flooding, earthquakes, etc.), sometimes it is part of the coping strategy (insurance) and sometimes it is just another urge on the policy agenda (urban issues). Another theme is the interplay between mitigation and adaptation strategies. Elements of both can be observed in many papers.

\subsection{Science-policy relations}

As mentioned before, the issue of climate change is very complex. We are faced with huge uncertainties about cause-effect relations. But decisions need to be made before conclusive evidence becomes available. The problem could be labeled as a 'wicked problem' because we are dealing with a completely new phenomenon associated with large-scale environmental and social change (Van Bueren et al., 2003; Termeer \& Kessener, 2007). In addition, we are discussing a distant and therefore unforeseeable future. The solutions to the associated problems are not evident. In this situation, there cannot be a linear relation between science and policy, i.e. a relation where science decides what exactly the problem is, what kind of scientific knowledge is relevant and should be transferred to politicians and what climate adaptation policies should look like. Multiple stakeholders (individuals, pressure groups, NGOs, governments and businesses) at different levels (local, regional, national and international) will have different ideas about these issues. Therefore, many scholars stress that there is a need to include the voice of the people in order to be able to effectively cope with the problem of climate change. Moreover, because of very different value systems, people in different cultures will have differing views as to what the problem is and how it should be solved. The question who carries the responsibility to take action is not easily answered either.

In the literature on governance attention is being devoted to the relationship between science and policy. There is a large amount of empirical evidence that the relation between science and policy in practice is complex and versatile. What can be observed is that there is a two-way flow of 
communication and influence between the two, but at the same time, the relation is problematic. Many scholars, business men, civil servants and politicians observe a tension between research agendas and research outcomes on the one hand, and the need for certain policy relevant knowledge on the other. For instance, the knowledge that climate policies require calls for research, and research institutes play a significant role in processes of establishing research agendas, research networks and the dissemination of knowledge. But only a tiny part of this research seems to be used in policies and politics. In other words, the relation between science and policy remains disputed. A crucial question is what the science-policy interface should look like.

The science-policy interface brings in a new approach to the issue of climate adaptation. The interface is the coming together of two distinct worlds: that of academia and that of policy making. Some authors involved in the debate argue that a more effective and efficient fusion of the two worlds should be stimulated (e.g. Parson et al., 2003: 10; Arvai et al., 2006: 218): there is a gap to be bridged. Others go less far and state that there is at least a need for rethinking the relation between science and policy (Wynne, 1992; Funtowicz \& Ravetz, 1993; Nowotny et al., 2001).

Although most of the literature on the science-policy interface does not relate directly to issues of climate change and climate adaptation policies, we can distinguish some interesting and promising approaches. These approaches do not fundamentally differ, but they each emphasise other relevant aspects in the difficult and intriguing relation between science and policy.

The first approach emphasises aspects such as uncertainty and complexity in science-policy interaction. Proponents of this approach are for instance Wynne (1992) Funtowitz \& Ravetz (1993), Nowotny et al. (2001) and Van der Sluijs $(1997 ; 2005)$. The point of departure in this approach is that we have to deal with uncertainties in one way or another, rather than trying to reduce them. Uncertainty is seen as intrinsic to complex systems and a fact of life. Furthermore, this view acknowledges that not all uncertainties can be quantified and that unquantifiable uncertainties are relevant as well. This view stands up for more qualitative and reflexive approaches to uncertainties, using participatory decision methods.

In a second approach, the relation between science and policy is interpreted as 'boundary work'. From this view science and policy are seen as two different entities with a boundary in between. Stimulating a mutual relationship between the two means establishing boundary arrangements. Boundary work is like a living-apart-together relationship. In science-policy boundary work the challenge is to institutionalise the boundary, and yet keep sufficient tension and confrontation for productivity, novelty and creativity. Mutual knowledge exchange and co-production of new expertise are the key concepts of this approach. Boundary work arrangements can differ per policy sector (water, nature, spatial planning, etc.) or per scale (international, national, regional). Proponents of this approach are among others Hoppe (2008), Guston (2001) and Miller (2001).

A third approach can be labelled as 'transdisciplinarity' or 'transdisciplinary transition processes'. This approach contains elements of the former two approaches because it acknowledges the uncertainties and incompleteness of any type of knowledge and the need for mutual learning between science and society. Transdisciplinary processes are conceived as a key element of societal capacity building, especially of developing socially robust knowledge. These processes could be characterized by (a) joint problem definition, (b) joint problem representation, and (c) jointly initiating a process of problem solving. It is obvious that processes of transdisciplinarity go along with public participation in knowledge production, knowledge dissemination and decision-making. Proponents of this approach are Scholz (2000) Scholz \& Tietje (2002), Thompson Klein (2001), and Gibbons (2001).

A fourth approach is developed by Pielke (2007) and starts with a simple demand (can users benefit from research?) and supply (is relevant information being produced?) scheme. Based on this scheme indications arise where opportunities to connect science and decision-making are successfully used or have been missed. Moreover, the importance of the institutional context is emphasised. Decisions emerge within institutional contexts. In turn, these contexts help to determine what types of information may be useful for decision-making. As Pielke $(2008$, p.5) states: "Supply and demand must ultimately be reconciled within science policy institutions, such as relevant government agencies, legislative committees, executive offices, non-governmental advisory groups, etc. Institutional attributes such as bureaucratic structure, budgeting, reporting requirements, and avenues of public input, combine with less tangible factors including the ideas and norms embedded within an institution, to drive decision- 
making about the conduct of research and the utility of results". Furthermore, according to Pielke experts can play different roles in decision-making processes. He distinguishes between roles such as the pure scientist', 'the science arbiter', 'the issue advocate' or 'the honest broker of policy options' (Pielke, 2007).

A fifth approach sees the unavoidable processes of social change - as a consequence of the changes that are occurring in the physical domain - as transition processes and systems innovations that have to be managed. In many cases, climate adaptation strategies require changes in established patterns of (collective) action which are so profound that also changes in the structural context are needed. In such cases, these strategies may be seen as (parts of) a 'system innovation': a coherent change in established patterns of action in a particular system (e.g. greenhouse farming or river management) and the structures in which they take place (Grin et al., 2003). Systems innovations are often part of a wider process of change involving several systems and often leading to a re-definition of their boundaries and alignment (e.g. between water management and spatial planning): a transition (Rotmans et al., 2001).

In a last approach, a systems perspective is also used. Within this approach not the social system is debated, but the science system. It investigates the dynamics directly involved in scientific and technological development: how is the system of science organised, how does it respond to scientific, social and economic developments, and what substantial scientific developments does this lead to? One of the analytical tools in this approach is the so-called 'science system assessment', an evaluation of the functioning of a specific science system (Van den Besselaar, 2006; Vasbinder \& Kern, 2005). 


\section{Research agenda}

\subsection{Introduction}

The assessment of the social sciences literature relevant to governance of adaptation has led to a state-of-the-art overview. Moving from there to a research agenda is taking the step from knowing what is available to what is missing. And from all that is missing, i.e. the unknown, only a slight extent can and should be designated as being part of a potential research agenda. Guiding principles in this respect have been (a) the comparison of the themes, (b) the suggestions for further research supplied by the literature and (c) the personal expertise and experience of the researchers. In that respect, the context of the Dutch case and approach to adaptation in general, and the aims of the Knowledge for Climate programme in particular have been crucial. As a consequence, the proposed research agenda should by no means be considered as exhaustive. It is an attempt to establish the adaptation assignment as a social challenge and, more particularly, as a research agenda for governance of adaptation. The suggestions range from broader themes and aspects to more specific studies and foci.

Of course, the demarcations between the research themes outlined in the previous chapter are rough in the sense that more specific themes, or sub-themes could be designated, and in the sense that the boundaries between them are permeable. In that respect, it has to be noted that connections between the themes can be worthwhile. As a consequence, when thinking through the research agenda, by means of an iterative deductive-inductive process, cross-thematic research topics for future research should also be taken into account. Knowledge lacunas could lie in the absence of promising connections between the themes.

\subsection{Conceptual frameworks}

\subsubsection{Critically scrutinising the normative concept of adaptability}

Because socio-ecological systems are studied as complex adaptive systems, the notion of adaptability, in order to increase resilience and decrease vulnerability, is a very important one (Carpenter et al., 2001; Folke et al. 2005). As a consequence of this normative judgment, all concepts are directed to the improvement of adaptability through adaptive management and adaptive governance. This normative starting point of the adaptation literature is more or less taken for granted. It would be helpful to critically scrutinise the notion of adaptability in two directions. The first direction is investigating the concept of adaptability within the field of climate change. Are modes of adaptive governance better able to adapt to climate change than other modes of governance? Historically seen, for example, many big investments were made as a reaction to crisis, e.g. a lack of adaptability. In this research also the critics of ecologists on the conservative character of the concept of resilience might be useful. The second direction implicates a comparison of adaptability with other concepts used to qualify governance systems, such as democracy, transparency, reliability or efficiency. In this context the notion of Weick \& Sutcliffe (2001) who plead for a powerful combination of both encouraging variety, responsiveness and learning and promoting order, decisiveness and reliable performances is challenging. A more general question in this respect is to what extent the situation as described in the above is typical for climate change and adaptation. In addition, it should not be excluded that modes of governance other than the ones mentioned here could also be suited for the climate adaptation issue.

\subsubsection{Practical evidence of adaptive management/governance in the field of climate adaptation}

Adaptive management is mainly developed in the context of natural resources such as water management, forestry or nature conservation. Although most literature is on the theoretical framework scientist are also experimenting with putting the concepts into practice ${ }^{3)}$, for instance New approaches to adaptive water management under uncertainty. Many authors almost automatically relate adaptive governance to climate adaptation. The concept of adaptive management provides such a theoretically appealing framework that Arvai et al. (2006), for example, recommend the approach to the IPPC, that currently mimics too much the non-adaptive policy world. However, until now literature does not provide elaborated examples of successful and unsuccessful (or even bad) adaptive management in the field of climate adaptation. To fill up this gap, and to prevent a jumping to conclusions, further

\footnotetext{
${ }^{3)}$ See for instance the NeWater project (www.newater.info)
} 
research is needed into the practical experiences with adaptive management strategies. It would be fruitful to compare these adaptive strategies with other ones, for example the planning strategy as promoted by the Dutch Delta Committee.

\subsubsection{Other governance concepts for managing uncertainty and unpredictability}

The ambitious challenge of adaptive management is to develop a more realistic and promising way to deal with ecosystem complexity (Folke et al., 2005). It promotes the challenge to really accept uncertainty, to be prepared for change and surprise, and to enhance the adaptive capacity to deal with disturbance (Folke et al., 2005: 464). Although not referred to explicitly, we assume that the authors qualify monocentric governance systems, dominated by planning and control as non-adaptive. In this sense the adaptive governance literature subscribes mainstream governance literature, proclaiming a shift from hierarchical and well-institutionalised forms of government towards horizontal and less formalised forms of governance. However, fewer references are made to recent governance concepts that focus on dealing with dynamics, unpredictabilities and uncertainties. Examples can be found in the literature on transition management (Loorbach \& Rotmans, 2006) and network governance (Klijn and Koppenjan, 2000; Koppenjan \& Klijn, 2004). As argued above these scholars of public administration and politics have not published on cases in the field of climate adaptation. Applying this concept on climate adaptation can generate challenging options for further research. It should be avoided, as it is suggested here, to reinvent the wheel in this respect.

\subsubsection{Incrementalism and punctuated policy change}

Adaptive governance resembles much of what the political scientist Wildavsky has described as incrementalism. It is not only an empirical but also a normative model. Already in 1988 Wildavsky pleaded for an improvement of the general capacities of governmental institutions "to investigate, to learn, and to act, without knowing in advance what one will be called to act upon". (1988, p. 70). Since then policy change gained much attention. It were True, Baumgartner \& Jones who developed the punctuated-equilibrium theory to explain the pattern of policy stability (or small incremental changes), which are occasionally interrupted by abrupt major policy changes (True, Jones et al., 2007). In times of stability this involves prioritising the ongoing incremental policy. When priorities shift, big policy changes may result. When a certain issue rises to the top of the policy agenda (e.g. climate change), pressure on politicians to take action increases, new actors may mobilise and current policies are attacked. Further research could flesh out the interference between incremental and abrupt policy changes in the field of climate adaptation, both from an empirical and a normative point of view.

\subsubsection{Theoretical multiplicity}

The main authors in the field of adaptive management and adaptive governance address many interesting themes and concepts. Most of them, for example Folke et al. (2005) and Biermann (2007), try to integrate all these concepts in one theoretical framework. Although the different notions are all very important and interesting the total picture becomes a little confusing and abstract. It is not very clear how all this variety needs to be handled. In an overview paper on transition management we suggested an approach of theoretical multiplicity for dealing with the enormous challenge of sustainability, pleading for multiplicity (Dewulf et al., 2008). Our main argument was "that steering societal developments in areas as complex as sustainability is unlikely to be successful when only one theory is used, especially when the relevant time frame extends over one or more generations". As climate adaptation is one of such enormous challenges we plead for a multiplicity in disciplines and approaches. With the powerful concept of "governance in the shadow of hierarchy" Scharpf (1998) also introduced the concept of multiplicity. Nowadays it is mainstream to search for a smart combination of modes of governance to deal with complex problems. Further research is needed to investigate the value of multiplicity in the field of climate adaptation, for example by investigating one case with different theoretical perspectives.

\subsubsection{The dark side of politics}

It can be concluded that because adaptive management is mainly framed as a process of experimenting and social learning - Pahl-Wostl even defines adaptive management as "a systematic process for improving management policies and practices by learning from the outcomes of management strategies that have already been implemented" (Pahl-Wostl 2007: 4) - other aspects are somehow neglected. Here we mention the role of power, conflicts, strategic behaviour, policy games or actors hindering adaptation. A certain naivety in current approaches to the highly complex issue of 
climate adaptation, perhaps, has been sneaked in. Central to politics is the manipulation of power and authority. Analyses of climate adaptation in terms of power games can fill this gap.

\subsubsection{Designing innovative institutional arrangements}

Authors stress the importance of institutional arrangements that provide cross-scale interactions; encourage reflection; enable self-organisation, etcetera. However, less attention is devoted to the design of these arrangements. What kind of arrangements can be thought of, what are the experiences with different forms of arrangements, what rules of thumb can be developed to design these arrangements, how can these arrangements be realised within the existing institutional structures?

\subsubsection{Trajectory management}

We started this paper by stressing the specific features of the climate adaptation challenge. As far as we can see most concepts and frameworks especially focus on the characteristics of multiple actor setting, uncertainties and unpredictabilities. The characteristic of the 'long term' is somehow undervalued. From this point of view it would be very interesting to further elaborate the concept of trajectory management (Van der Knaap et al., 2004). This concept aims to develop long term policy trajectories without suppressing the polycentric character of policymaking, and without neglecting processes of learning and change.

\subsubsection{Changing governance}

One main assumption in most articles is that new forms of governance are needed in order to tackle the climate adaptation problem. However, implementing new governance concepts is difficult, above all when they conflict with the rules and beliefs of existing governance institutions (Termeer and Kessener, 2007). Even when actors really want to bring into practice new forms of governance they will meet all kinds of barriers embedded in existing institutions (Termeer, 2009). Dealing with climate adaptation problems not only asks for us to rethink how we arrange our social-ecological systems, but also how we govern them. In other words dealing with problems in a renewed way involves an ongoing and fundamental review of the governance system itself. Concepts from change management can be very fruitful to further study the transitions within the governance systems.

\subsection{Assessment tools}

We have seen that governance of adaptation implies the coming together of the social world and the biophysical world. The core of the problem, as has been argued, lies in the latter sphere, although it is the human interest which defines it as a problem. And even more so, in addition to autonomous climatic development, human behaviour also induces climate change. The whole situation can thus be characterised as one of utter complexity and uncertainty. To operate under such circumstances, and aim to adapt to climate change, a wide range of assessments and assessment tools are needed to acquire knowledge of the past and present, but particularly of the future, where uncertainty lies. Within the theme on assessment tools and based on the assessment of the literature review underlying this study, several suggestions for future research would seem feasible.

\subsubsection{Mitigation-Adaptation trade-offs and demarcations}

Although mitigation and adaptation seem two different approaches to the same problem, they are in fact two sides of the same coin, with uncertainty as the common core. They could be implemented separately, the trade-off between the two constitutes the ultimate challenge for both scientists, industry and policymakers. "Despite longstanding calls to exposure synergies and trade-offs between adaptation and mitigation to climate change and to develop integrated strategies, the need for such work has only recently been broadly recognized" (Goklany, 2007: 756; see also Klein et al., 2005; Kok \& De Coninck, 2007). Fully unravelling this unfathomable complexity might not be feasible for humankind, but does put the problem into its ultimate context. Putting things straight can be instrumental in the agenda-setting process. As was stated at the start of this report, a priority position at the political agenda must be taken for granted. Keeping the assessment motor running, however, keeps feeding the world with new information, either sustaining the existing knowledge or questioning it. Solid assessments can contribute to convincing the public of the need for both mitigation and adaptation, now and in the future. In addition, more and better assessment results can help to get rid of the stigmata held by the public that climate change and adaptation are fashionable topics that are 
not here to stay, only promoted by the 'climate church'. Blurred boundaries between mitigation and adaptation can also be misleading in that respect, when informing the public ${ }^{4}$.

Mankind has always been adapting itself to changing environments and the consequences of its being and consuming on that same environment will only become more and more relevant for its well-being. As a consequence, investing in assessment tools is a safe investment, hence an opportunity for countries, industries and scientists. Tackling uncertainty is a constant quest for heterogeneity, hence a competitive advantage, in each of these spheres. Social scientific research is the medium par excellence to catalyse the knowledge needed for that, for instance by providing a continuous stream of state-of-the-art research and by performing as the academic hub to present comprehensible knowledge to the public, captains of industry and policy makers. A risk-avoiding society appreciates those who mitigate uncertainty.

\subsubsection{Knowledge dissemination and enhanced decision support systems}

In the above, it has been argued that climate adaptation involves uncertainty both in the biophysical and social spheres. In addition, it has been contended that social sciences should be involved in biophysical uncertainties in the sense that the subsequent knowledge has to be made available beyond the walls of science. The opposite is no less relevant. Also, social sciences have their own relevant material object of study, hence academic responsibility, in this respect: social dynamics. Society as a whole, and policymakers in particular, will need to make decisions on adaptive measures more and more. Furthermore, the amount of information made available, for instance to reduce uncertainty, will only increase in the years to come, without necessarily always pointing in the same direction, leave alone corresponding with the societal stakes involved. In order to prevent data asphyxiation or information short-cuts hampering decision making processes, more research will be needed to enhance decision support systems.

\subsubsection{Non-linearity and shock events: damage control}

The theme of assessment tools draws attention to the temporal aspect of climate adaptation, separating the unknown future from what has passed. The connection between the two are trends and developments that scientists are trying to capture by modelling. Models usually do not stand out in explaining disruptive phenomena or the unexpected. Social sciences in particular are not equipped to explain or forecast shock events. The role of shock events in history, often featuring both ecological and social radical changes, is undisputed however. From the perspective of governance of adaptation it would thus be worthwhile to mitigate the uncertainty about what would happen if preventive measures were to fail at certain point. These are the ultimate momentums of uncertainty, when all efforts to tackle uncertainty appear to be in vain. In other words, the notion of uncertainty also, or particularly, point in the direction of such shock events. Once the moment is there, all that can be done is damage control. Like the crucial first few minutes after a heart attack, the first few minutes, hours or days after a disaster largely determine the scale of damage. Counting from the moment of impact, for instance a flood, the first concern is to save as many souls as possible. Only thereafter do other concerns, such as the well being of people, economic traffic and restoration of daily life, prevail (cf. Norris et al., 2008). That ultimate concern, the lives of people, seems a surreal situation, which is the reason why we speak of a shock event in this respect, but even recent history shows such situations repetitively. Governance of adaptation should also incorporate research on shock events and damage control, for instance by looking at the literature on crisis management.

\subsubsection{Risk perception}

Approaching climate adaptation in terms of uncertainty, as this theme on assessment tools implies, points the finger at the notion of risk. The assumption of the human risk-avoiding nature has been stressed in the above. Risk however is a social construct, linking uncertainties in the future with actual behaviour. As a consequence, risk perception can be regarded as a driver for daily action. Not only in the short run, for example when people want to flee to the safest area in the case of a flood, but also from a long term perspective, for instance when a house is being bought. The aggregation of these individual risk perceptions and subsequent agency implies major social dynamics relevant for the theme of adaptation to climate change. To elaborate on the first example, government should want to know what behaviour can be expected from citizens when a climate disaster strikes a particular area. Both ex-ante (e.g. instructing and preparing the people) and ex-post measures (e.g. putting into

\footnotetext{
4) Goklany (2007) sums up some misconceptions that could hinder fuller integration of adaptation and mitigation.
} 
practice safe havens) could thus be implemented. Taking the second example, city planners and insurance companies will be interested in where and under what circumstances people would like to settle.

As appears from the above, risk perception, is to a large extent location specific. People living near the coast will have other perceptions than those living inland on relatively dry areas. Nonetheless, people in the latter situation will not by definition be free from any climate concern, hence risk perception. Draught and heat stress will also confront these areas with the consequences of climate change. Besides health concerns, other stakes can also be designated as relevant and significant. For instance, the economic stakes of a relatively small piece of land such as an airport or harbour can be of national, or even international, significance. As a consequence, risk perceptions of foreign investors also come in the picture. The argument for considering risk as a social construct has been made in the above. People do not live in a vacuum, but are continuously in contact with other people. In interaction with each other, they 'negotiate' on the meaning they give to their surroundings: what is happening, what do we think of it, what do we not know yet, what does that mean for our actions, which outcomes do we expect, etc. By constructing stories with others, actors make sense, to themselves and others, of their actions. (Termeer and Kessener, 2007) In processes of sense-making risks are constructed. In this respect, the role of government deserves specific attention, as the policymakers and politicians play a crucial role in the framing of the climate adaptation issue, deliberately or not. To what extent, for instance, must government create the adaptation problem? Taking into account the above, it is fair to state that much research needs to be done in order to assess risk perceptions as an important factor in implementing adaptation strategies.

\subsubsection{Investigation of potentially useful assessment tools}

As has been argued in the above, the literature on governance of adaptation reveals claims for improving and improved application of assessment tools, particularly taking into account the social complexity of the issue. We expect that much potentially useful knowledge and expertise is already available, but has not been connected to the climate adaptation issue (Mickwitz et al 2009, 77-78). It is thus encouraged here to explore this potential of existing assessment tools: what is already available, has delivered useful insights, and has potential for climate adaptation?

\subsection{Adaptive policies and strategies}

\subsubsection{Towards new concepts of climate-proof (urban) development strategies}

In urban and regional planning the integration of external priorities (or interests) within planning processes and procedures is a common phenomenon. It is referred to as the principle of 'external integration' (see also Spit \& Zoete, 2006: 96-99) or 'environmental policy integration' (Lafferty and Hovden, 2003; Nillson and Persson, 2003; Jordan and Lenschow, 2008; Runhar et al, 2009; Mickwitz et al, 2009). It reflects the general ambition to optimise planning processes. Yet, the battle for better positions of the involved sectoral interests is not without its winners and losers. Traditionally, the economic strong interests (such as financial gains, employment etc.) are best off in this fight. The weaker interests (the long term and costly, such as nature development) are mostly on the other side. Dependent upon their position within the planning concept the traditional positions can be weakened or strengthened.

Climate-proof elements can be considered as belonging to the weaker interests. For they represent long-term and costly public interests. The shift towards a more market led planning in the Netherlands can be considered to disadvantage the position of climate-proof elements, as market forces are profit led. Nevertheless, as more and more new conceptual planning arrangements are constructed in which the weaker interests can be combined with the stronger, new challenges emerge.

One of the most difficult things to organise in spatial planning processes is to combine long-term goals with short-term objectives. This cuts across every stage of a planning process. Both, theoretical and methodological in long term planning the differences are immense. New concepts or adjustments of existing ones can help to overcome the fundamental differences, both in terms of contents as in terms of planning processes. Literature shows that planning processes are becoming more and more complex, especially when large projects are involved (Flyvbjerg et al., 2002; Flyvbjerg et al., 2003). This development did not pass the Netherlands unnoticed. On the contrary, research shows that these findings apply especially for Dutch spatial planning (Commissie Duivesteijn 2000; Spit \& Zoete 2006). 
The ambition to maintain and enlarge the leading positions of the mainports Rotterdam and Schiphol, urges the need to develop knowledge on the subject of how to integrate climate change aspects into these already very complex planning processes.

\subsubsection{Integration of adaptive policy measures into land development processes}

One of the fundamental issues in development processes is land policy (Kruijt et al., 1992). A smart organisation of land development processes with the use of land policy instruments can provide a fruitful entrance for climate-proof policy measures. However, a similar approach is often tried and used by other sectored interests. Therefore, this road is not unproblematic. A clever combination of legal instruments with land use into land development processes can provide a major help to accomplish this goal. Of course, the research can be directed towards different types of land use. In the Netherlands e.g., a huge redevelopment programme lies ahead with regard to business parks. There are many new possibilities to integrate climate-proof elements into the programming of this redevelopment scheme (Van Dinteren, 2008). A similar reasoning can be held for the coast line redevelopment programme. In this redevelopment scheme several types of other land use and recreational activities can be integrated. Although land development processes are very operational in character, a long-term view of the development goals and objectives on a regional scale also plays an important role. Therefore, a complex process develops itself: a relatively 'hard' short-term development process, within a regional context of 'soft' conditions and long-term goals. Adaptive policy measures towards climate change, can play a role in both, but its 'natural' place is within the 'soft' context of conditions and goals. The issue at stake is how these contextual elements can better be integrated into the actual land development process.

\subsubsection{Land policy and restructuring the urban landscape}

Relatively new is the idea that climate change affects the urban environment. The existing (research) programmes hardly include any aspects which refer to climate change, although there is some awareness of its importance. Reference is sometimes made to the existence of heat islands, but the most prominent climate-related subjects are 'water-related'. Not only concern for heavy rain (and drainage systems), but also groundwater problems, canals, etc. Restructuring the urban landscape implies a planning approach in which all these aspects can be integrated in a more or less flexible way. The balance between flexibility and robustness is traditionally a delicate one in which the introduction of climate-proof elements can change this balance drastically. In order to improve the position of these elements, they can best be linked with land policy (instruments).

\subsubsection{Evaluation of finance principles}

The basic principles for the finance of land (re)development can either be found in the market mechanism, or in government subsidies. Nowadays, however, more and new principles can be found in the 'twilight zone' between the public and private domain. As the principles differ fundamentally it is very interesting to search for creative combinations in terms of linkages (Alterman, 1989), value creating combinations (Baaré 2007), etc. This search for new instruments and strategies must be based upon a thorough evaluation of the existing mechanisms, such as compensation.

\subsubsection{Comparing delta regions}

In planning literature (see e.g. Dieleman et al., 1998, Atkinson \& Rossignolo, 2008) there is a rich tradition of comparative studies. The concept behind this tradition is that in urban and regional planning, similar problems, issues and processes can be found all over the world and there are lessons to be learnt from all of these experiences. A similar reasoning would be valid when adaptive strategies towards climate change in delta regions are considered. Not only are there many lessons to be learnt, but there are also many regions which can learn from the Dutch experience. It is clear, however, that no concept can be adopted with the same results in every delta region or country (Swart et al., 2009). Every concept has to be adapted to the specific physical, social, legal and political circumstances of each and every individual case. In order to accommodate this condition, extensive knowledge has to be built of every case (including the Dutch).

\subsection{Science-policy relations}

Notwithstanding the fact that there seems to be a great deal of literature on science policy interface, there is little known about how we could arrange better links between climate (adaptation) science and climate science policies on the one hand, and climate (adaptation) policy and politics on the other. 
Climate adaptation science is a relatively new field of scientific and applied research. It has the ambition and the ability to be useful for the development of regional, national and international adaptation strategies. A crucial question is how in this respect to establish a fruitful and effective interrelation between science and policy, within a context of a versatile climate problem, multiple actors, differences in interests and values, and differences in political and organisational systems. Applying the science-policy interface and subsequent literature, as analysed in the previous chapter, to the notion of governance of adaptation leads to several suggestions for further research, of which the most pregnant will be discussed in the following.

\subsubsection{Handling scientific uncertainty in policy development}

As has been contended in the above, our knowledge on climate change is highly imperfect. Moreover, knowledge on this problem will stay incomplete and partly uncertain. Scientific research will indeed be able to reduce some of the knowledge gaps, but the uncertainties will not go away, no matter how much research is invested. Therefore we have to deal with uncertainties and the incompleteness of climate change knowledge in regional, national and international climate change policies. First, research could be conducted to explore the significance and characteristics of these uncertainties. Second, research is relevant on strategies that could be applied in order to cope with uncertainties in policy development and implementation.

\subsubsection{Analysis and evaluation of science-policy interactions in climate policies so far - lessons to be drawn}

The science-policy interface features the nexus of all scientific and social input. The 'pressure' to convert all that into adaptation strategies, let alone making the right decisions, is immense. From that perspective, the outcomes of the science-policy relationships can be considered as the proof of the pudding. A comforting thought, though, is the realisation that science and policy have a long history of collaboration already, apart from the climate adaptation issue, and despite the infant state that the study of boundary work finds itself in. In other words, there is a lot to be learned from ongoing and past experiences already, also in the field where those involved in climate adaptation work. More empirical research on the practice of science-policy relationships is thus encouraged here. There is a need for analysis of regional, national and international policies, also from a comparative angle, including international comparisons. What roles do the various experts play and which stakeholders are involved in the research agendas, the research development, research implementation and evaluation? The value of knowledge dissemination and validation has already been argued in the above, but from a science-policy perspective it would be worthwhile to see what lessons can be learned.

\subsubsection{Designing boundary arrangements and/or transdisciplinary processes at the regional and national level}

With respect to climate adaptation, scientists and policymakers are destined to one another. This interdependence will only increase in the future. Along comes with it the question where responsibilities lie. Everybody involved in climate adaptation will need to be aware of the impulses and demands from each side of the policy-science interface. Only then can an effective and efficient interaction take place. This interaction process is a process of co-production. More prescriptive research is needed on that. How to organise the co-production of new knowledge on climate adaptation? This requires a methodology of advice-giving which takes into account strategies of situational validation, strategies for trust-building and maintenance in the institutionalised relationship with policy workers and stakeholders, and strategies of social robustness of expert advice. Coproduction also requires dual accountability and legitimisation. How should that best be organised and under what conditions can stakeholders meet the dual accountability structures? Also, more research could be conducted on how to incorporate stakeholders' views in the development of research agendas and research projects. How can the development of process and outcome criteria of boundary arrangements and transdisciplinary processes be carried out best? The case of the Knowledge for Climate research programme works with so-called hotspot teams that face these questions on a daily basis. The hotspot coordinators manage hotspot teams, the research teams and consortia, each with practitioners, scientists and policymakers in it. In other words, there is an immediate and practical demand for research on how to arrange boundary arrangements and transdisciplinary processes. The current practice also directs towards another research suggestion. 


\subsubsection{Science system assessment}

The pioneering phase that adaptation as a boundary enterprise finds itself in implies a unique opportunity to accompany the juvenile science system with assessment arrangements. The benefits of a science system assessment for governance of adaptation are threefold. Firstly, monitoring enhances accountability towards stakeholders, including the tax payers. Secondly, it supplies grounds for improving the process of adaptation. Thirdly, it can serve as a carrier for knowledge, for instance by supplying benchmarks for other complex governance arrangements or adaptation abroad. It is thus encouraged to implement a science system assessment for the Dutch adaptation approach, as anchored within the national research programme Knowledge for Climate. 


\section{Conclusion}

Adaptation to climate change is, in practice, a social and institutional process. More specifically, we have argued that adaptation to climate change is a matter of governance. The body of literature on governance has supplied useful tools and insights to deal with wicked problems. Adaptation to climate change can be considered as an example of a wicked problem. The issue involves many actors, sectors and scales, hence significant barriers to reaching consensus. Moreover, values involved portray fundamental conflicts. In addition, the knowledge and information needed and available is not sufficient and sometimes even considered controversial. And not in the least, the problem crosses all thinkable boundaries and routines, requiring both immediate action and long-term horizons.

Governance interpreted as the mode of horizontal interactions between public and private parties through both formal and informal structures in order to solve complex societal problems implies a promising approach to the adaptation to climate change. A systematic review of literature within the domains of (I) environmental studies, (II) planning and development, and (III) public administration has led to the demarcation of four general themes relevant to our notion of governance of adaptation: (1.) conceptual frameworks, (2.) assessment tools, (3.) adaptive policies and strategies, and (4.) sciencepolicy relations. For each of the four themes, a research agenda has been formulated and argued, based on the literature study.

We have come to the conclusion that the field of (governance of) adaptation to climate change is dominated by the natural sciences or scientists that have a background in that part of the scientific community. Much knowledge within the social sciences has been left unused and relatively little attention has been paid to organisational and institutional dynamics. Our paper aims to increase the relevance of the social sciences approach to the issue of adaptation to climate change. 


\section{References}

Adger, W. N. (1999). Social vulnerability to climate change and extremes in coastal Vietnam. World Development, 27(2), 249.

Adger, W.N. (2001). Scales of governance and environmental justice for adaptation and mitigation ofclimate change. Journal of International Development, 13, 921-931.

Adger, W.N., P.M. Kelly \& H.N. Nguyen (2001). Living with environmental change: social vulnerability, adaptation and resilience in Vietnam. London; New York: Routledge.

Adger, W.N., T.P. Hughes, C. Folke, S.R. Carpenter \& J. Rockstrom (2005). Social-ecological resilience to coastal disasters. Science, 309(5737), 1036.

Agrawala, S., M. van Aalst (2008). Adapting development cooperation to adapt to climage change, Climate Policy, 8(2), 183-193.

Al-Jeneid, S., M. Bahnassy, S. Nasr, \& M.E. Raey (2008). Vulnerability assessment and adaptation to the impacts of sea level rise on the Kingdom of Bahrain. Mitigation and Adaptation Strategies for Global Change, 13, 87-104.

Alterman, R. (1989). Evaluating Linkage, and Beyond. Cambridge. Massachusetts: Lincoln Institute of Land Policy.

Armitage, D., M. Marschke \& R. Plummer (2008). Adaptive co-management and the paradox of learning. Global Environmental Change, 18(1), 86-98.

Arts, B., P. Leroy (eds.) (2006). Institutional Dynamics in Environmental Governance, Springer, Dordrecht.

Arvai, J., G. Bridge, N. Dolsak, R. Franzese, T. Koontz, A.Luginbuhl, P.Robbins, K. Richards, K. Korfmacher, B. Sohngen, J. Tansey, \& A. Thompson (2006). Adaptive management of the global climate problem: bridging the gap between climate research and climate policy. Climatic Change, 78(1), 217-225.

Baaré, D. (2007). De meerwaarde van waardecreatie: op het grensvlak van infrastructuur en gebiedsontwikkeling. Utrecht, Universiteit Utrecht (master thesis)

Barker, T. (2003). Representing global climate change, adaptation and mitigation. Global Environmental Change, 13(1), 1-6.

Barnett, J. (2001). Adapting to climate change in pacific island countries: the problem of uncertainty. World Development, 29(6), 977 - 993.

Beck, U. (1992). Risk society: towards a new modernity. London; Newbury Park, California: Sage Publications.

Berkhout, F. (2005). Rationales for adaptation in EU climate change policies. Climate Policy, 5(3), 377391.

Berkhout, F., J. Hertin, \& A. Jordan (2002). Socio-economic futures in climate change impact assessment: using scenarios as learning machine. Global Environmental Change, 12(2), 8395.

Berkout, F., J. Hertin, A. Gann, (2006). Learning to Adapt: Organisational Adaptation to Climate Change Impacts. Climatic Change, 78(1), 135-156

Berry, P.M., M.D.A. Rounsevell, P.A. Harrison, \& E. Audsley (2006). Assessing the vulnerability of agricultural land use and species to climate change and the role of policy in facilitating adaptation. Environmental Science and Policy, 9(2), 189-204.

Biermann, F. (2007). 'Earth system governance' as a crosscutting theme of global change research. Global Environmental Change: Human and Policy Dimensions., 17(3), 326.

Blatter, J. (2003). Beyond Hierarchies and Networks: Institutional Logics and Change in Transboundary Spaces. Governance, 16(4), 503-526. 
Breeman, G.E., \& A. Timmermans (2008). Politiek van de aandacht voor milieubeleid. Een onderzoek naar maatschappelijke dynamiek, politieke agendavorming en prioriteiten in het Nederlandse milieubeleid. Wettelijke Onderzoekstaken Natuur \& Milieu., 77.

Bronstert, A. \& Z. Kundzewicz (2006). Discussion of the article: "Forest and floods: moving to an evidence-based approach to watershed and integrated flood management. Water International, 31(1), 427-431.

Brooks, N., W.N. Adger, \& P.M. Kelly (2005). The determinants of vulnerability and adaptive capacity at the national level and the implications for adaptation. Global environmental change, 15(2), 151-163.

Brunner, R.D., T.A. Steelman, L. Coe-Juell, C.M. Cromley, C.M. Edwards, D.W. Tucker (2005). Adaptive governance: integrating science, policy, and decision making, Columbia University Press, New York.

Bulkeley, H. (2006). A changing climate for spatial planning. Planning, Theory \& Practice, 7, no. 2, 203-213.

Burton, I., L. Bizikova, T. Dickinson, Y. Howard (2007). Integrating adaptation into policy: upscaling evidence from local to global. Climate Policy, 7(4), 371-376.

Burton, I., S. Huq, B. Limc, O. Pilifosova \& E.L. Schipper (2002). From impacts assessment to adaptation priorities: the shaping of adaptation policy. Climate Policy, 145 - 159.

Calder, I.R., \& B. Aylward (2006). Forest and floods: Moving to an evidence-based approach to watershed and integrated flood management. Water International, 31(1), 87-99.

Callaway, J. M. (2004). Adaptation benefits and costs: are they important in the global policy picture and how can we estimate them? Global environmental change, 14(3), 273 - 282.

Carpenter, S., B. Walker, J.M. Anderies, \& N. Abel (2001). From Metaphor to Measurement: Resilience of What to What? Ecosystems, 4(8), 765-781.

Clark, M.P. \& R.S. Pulwarty (2003). Devising resilient responses to potential climate change impacts. Ogmius: newsletter of the Center of Science and Technology Policy Research. 5, 2-3.

Crabbé, P., \& M. Robin (2006). Institutional adaptation of water resource infrastructures to climate change in Eastern Ontario. Climate Change, 78(1), 103 - 133.

Dalhuisen, J.M., C.A. Rodenburg, \& H.L.F. De Groot (2003). Sustainable water management policy: lessons from Amsterdam. European Planning Studies, 11(3), 263-282.

Dessai, S., \& M. Hulme (2007). Assessing the robustness of adaptation decisions to climate change uncertainties: A case study on water resources management in the East of England. Global Environmental Change, 17(1), 59-72.

Dessai, S., X. Lu, M. Hulme (2005). Limited sensitivity analysis of regional climate change probabilities for the 21st century. Journal of Geophysical Research, 110(D19), D19108.

Dewulf, A., C. Termeer, R. Werkman, G. Breeman (2008). Steering system innovations - a theoretical exploration of transition management. Proceedings of the 15th Annual Conference on MultiOrganizational Partnerships, Alliances and Networks (MOPAN), June 25 - 27, 2008, Boston.

Dewulf, J., H. Van Langenhove, B. Muys, S. Bruers, B.R. Bakshi, G.F. Grubb, D.M. Paulus, \& E. Sciubba (2008). Exergy: its potential and limitations in environmental science and technology. Environmental Science \& Technology, 42(7), 2221-2232.

Diamond, J., \& J. Liddle (2005). Management of regeneration: choices, challenges and dilemmas. London; New York: Routledge.

Downing, T. (2003). Toward a vulnerability/adaptation science: lessons from famine early warning and food security, in: J. Smith, R. Klein, S. Huq (eds.), Climate change adaptive capacity and development, Imperial College Press, London, 77-100.

Duivesteijn, A. (2000). Rapport van de Tijdelijke Commissie Infrastructuurprojecten "Commissie Duivesteijn".

Edelenbos, J. (2005). Institutional Implications of Interactive Governance: Insights from Dutch Practice. Governance, 18(1), 111-134. 
Eriksen, S.H., \& P.M. Kelly (2007). Developing credible vulnerability indicators for climate adaptation policy assessment. Mitigation and Adaptation Strategies for Global Change, 12, 495 - 524.

Falconer, R.A., \& R. Harpin (2005). Catchment flood management: A U.K. perspective and experience. Water International, 30(1), 5-13.

Feldman, M.S., \& A.M. Khademian (2007). The Role of the Public Manager in Inclusion: Creating Communities of Participation. Governance, 20(2), 305-324.

Few, R., Brown, K., \& Tompkins, E. L. (2007). Climate change and coastal management decisions: insights from Christchurch Bay, UK. Coastal Management, 35(2-3), 255 -270

Fischer, F. (2003). Reframing public policy, discursive politics and deliberative practices. Oxford: Oxford University Press.

Flyvbjerg, B., N. Bruzelius, \& W. Rothengatter (2002). Big Decisions, big risks. Improving accountability in mega projects. Transport Policy, 9, 143 - 154.

Flyvbjerg, B., N. Bruzelius, \& W. Rothengatter (2003). Megaprojects and risk: an anatomy of ambition (7th printing ed.). Cambridge: Cambridge University Press.

Folke, C., S. Carpenter, T. Elmqvist, L. Gunderson, C.S. Holling, \& B. Walker (2002). Resilience and sustainable development: building adaptive capacity in a world of transformations. Ambio, 31(5), 437-440.

Folke, C., T. Hahn, P. Olsson, \& J. Norberg (2005). Adaptive governance of social-ecological systems. Annual Review of Environment and Resources, 30, 441-474.

Frederickson, D.G., \& H.G. Frederickson (2006). Measuring the performance of the hollow state. Washington, D.C.: Georgetown University Press.

Frederickson, H.G., \& K.B. Smith (2003). The public administration theory primer. Boulder, Colombia: Westview Press.

Funtowicz, S.O., \& J.R. Ravetz (1993). Science for the post-normal age. Futures, 25(7), 739.

Gallart, F., \& P.Llorens (2003). Catchment management under environmental change: impact of land cover change on water resources. Water International, 28, 334-340.

Gibbons, M.N. (2001). The potential of transdisciplinarit. Birkhauser Verlag, Basel.

Glasbergen, P. (1998). Co-operative environmental governance: public-private agreements as a policy strategy. Dordrecht; Boston: Kluwer Academic Publishers.

Glasbergen, P., \& P.P.J. Driessen (2005). Interactive planning of infrastructure: the changing role of Dutch project management. Environment and Planning. C, Government \& Policy., 23, 263278.

Glasbergen, P., F. Biermann, \& A.P.J. Mol (2007). Partnerships, governance and sustainable development reflections on theory and practice. Cheltenham, UK; Northampton, MA: Edward Elgar.

Goklany, I.M. (2007). Integrated strategies to reduce vulnerability and advance adaptation, mitigation, and sustainable development. Mitigation and Adaptation Strategies for Global Change, 12, $755-786$.

Grin, J., H. v.d. Graaf, \& P. Vergragt (2003). A third generation environmental policy: a sociological perspective and a policy scientific program. Beleidswetenschap, 1, 51-72.

Guston, D.H. (2001). Boundary organizations in environmental policy and science: an introduction. Science, Technology, \& Human Values, 26(4), 399-408.

Hahn, T., P. Olsson, C. Folke, \& K. Johansson (2006). Trust-building, knowledge generation and organizational innovations: the role of a bridging organization for adaptive comanagement of a wetland landscape around Kristianstad, Sweden. Human Ecology, 34(4), 573-592.

Hajer, M.A., \& H. Wagenaar (2003). Deliberative policy analysis: understanding governance in the network society. Cambridge, UK; New York, USA: Cambridge University Press.

Hanf, K., \& F.W. Scharpf (1978). Interorganizational policy making: limits to coordination and central control. London; Beverly Hills: Sage Publications. 
Hay, J.E., \& N. Mimura (2005). Sea-level rise: implications for water resources management. Mitigation and Adaptation Strategies for Global Change, 10, 717-737.

Held, D., A.G. McGrew (2000). The global transformations reader: an introduction to the globalization debate. Polity Press, Malden, Massachusetts.

Held, D., A.G. McGrew, D.Goldblatt, J. Perraton (1999). Global Transformations: Politics, Economics and Culture. Polity and Stanford University Press.

Hill, C.J., \& L.E. Lynn (2005). Is Hierarchical Governance In Decline? Evidence from Empirical Research. Journal of Public Administration Research and Theory, 15(2), 173-196.

Hoppe, R. (2005). Rethinking the science-policy nexus: from knowledge utilization and science technology studies to types of boundary arrangements. Poiesis and Praxis, 3(3), 199-215.

Hutter, G. (2007). Strategic planning for long-term flood risk management: some suggestions for learning how to make strategy at regional and local level. International Planning Studies, 12(3), 273-289.

IPCC, Cambridge University Press.

Jerneck, A., L. Olsson (2008). Adaptation and the poor: development resilience and transition. Climate Policy, 8(2), pp. 170-182.

Johnson, B.L. (1999). The role of adaptive management as an operational approach for resource management agencies. Ecology \& Society, 3(2), 8.

Jordan, A.J., A. Lenschow (2008). Innovation in Environmental Policy? Integrating the Environment from Sustainability. Edward Elgar, Cheltenham.

Kalibo, H.W., \& K.E. Medley (2007). Participatory resource mapping for adaptive collaborative management at Mt. Kasigau, Kenya. Landscape and Urban Planning, 82(3), 145-158.

Kettl, D.F. (2002). Environmental governance: a report on the next generation of environmental policy. Washington, D.C.: Brookings Institution Press.

Kickert, W.J.M., E.H. Klijn, \& J.F.M. Koppenjan (1997). Managing complex networks : strategies for the public sector. London; Thousand Oaks, California: Sage.

Kjaer, A.M. (2004). Governance. Malden, MA: Polity Press.

Klein, R.J.T., E.L.F. Schipper \& S. Dessai (2005). Integrating mitigation and adaptation into climate and development policy: three research questions. Environmental Science \& Policy, 8, 579 588.

Klijn, E.H. (2005). Netwerken als perspectief op beleid en uitvoering van beleid. Beleidswetenschap., 19(4), 32.

Klijn, E.H., \& J.F.M. Koppenjan (2000). Public management and policy networks: foundations of a network approach to governance. Public Management, 2(2), 135-158.

KNMI. (2008). De toestand van het klimaat in Nederland 2008. De Bilt: KNMI.

Kok, M.T., \& H.C. de Coninck (2007). Widening the scope of policies to address climate change: directions for mainstreaming. Environmental Sience and Policy, 10(7-8), 587-599.

Kooiman, J. (1993). Modern governance : new government - society interactions. London: Sage.

Koppenjan, J. \& E.H. Klein (2004). Managing uncertainties in networks. Routledge, London and New York.

Koppenjan, J., E.H. Klijn (2004). Managing uncertainties in networks. Routledge, London and New York.

Kruijt, B., B. Needham, \& T. Spit (1992). Economische grondslagen van grondbeleid. Amsterdam: SBV.

Lafferty, W., E. Hovden (2003). Environmental policy integration; towards an analytical framework. Environmental Politics, 12(3), 1-22.

Leary, N., J. Adejuwan, V. Barros, I. Burton, J. Kulkarni, R. Lasco (2008). Climate change and adaptation. Eartscan, London.

Lemos, M.C., \& A. Agrawal (2006). Environmental Governance. Annual Review of Environment and Resources., 31, 297. 
Leroy, P., \& N.J.M. Nelissen (2002). The paradigm shift in environmental policy research. Environment and Policy, 33, 227-244.

Leroy, P., N.J.M. Nelissen (1999). Social and political sciences of the environment; three decades of research in the Netherlands. International Books, Utrecht.

Lindseth, G., (2005). Local level adaptation to climate change; discursive strategies in the Norwegian context. Journal of Environmental Policy \& Planning, 7, pp. 61-83.

Loorbach, D., \& J. Rotmans (2006). Managing transitions for sustainable development. In X. Olshoorn \& A. J. Wieczorek (Eds.), Understanding industrial transformation: views from different disciplines. Dordrecht: Springer.

Mandell, M.P., \& T. Steelman. (2003). Understanding what can be accomplished through interorganisational innovations: the importance of typologies, context and management strategies. Public Management Review, 5(2), 197-224.

Marin, B., \& R. Mayntz (1991). Policy networks: empirical evidence and theoretical considerations, Frankfurt am Main; Boulder, Colombia.

Mata, L., \& J. Budhooram (2007). Complementarity between mitigation and adaptation: the water sector. Mitigation and Adaptation Strategies for Global Change, 12(5), 799-807.

Mayntz, R. (1993). Governing failures and the problems of governability: some comments on a theoretical paradigm. Modern Governance - New Society Government Interactions, 9-20.

McKenzie Hedger, M., R. Connell, P. Bramwell (2006). Bridging the gap: empowering decision-making for adaptation through the UK Climate Impacts Programme. Climate Policy, 6(2), 201-215.

Mickwitz, P., F. Aix, S. Beck, D. Carss, N. Ferrand, C. Görg, A. Jensen, P. Kivimaa, C. Kuhlicke, W. Kuindeersma, M. Manez, M. Melanen, S. Monni, A. Brandt Pedersen, H. Reinert, S. Bommel, (2009). Climate policy integration, coherence and governance. PEER report no. 2, Partnership for European Environmental Research, Helsinki.

Miller, C. (2001). Hybrid management: boundary organizations, science policy, and environmental governance in the climate regime. Science, Technology, \& Human Values, 26(4), 478-500.

Milward, H.B. (1994). Nonprofit contracting and the hollow state. Public Administration Review, 54(1), 73.

Milward, H.B., \& K.G. Provan. (1993). The hollow state: private provision of public services. Public Policy for Democracy, 222-237.

Nilsson M., A. Persson (2003). Framework for analyzing environmental policy integration. Journal of Environmental Policy \& Planning, 5, no. 4, pp. 333-359.

Norris, F.H., S.P. Stevens, B. Pfefferbaum, K.F. Wyche, \& R.L. Pfefferbaum (2008). Community resilience as a metaphor, theory, set of capacities, and strategy for disaster readiness. American Journal of Community Psychology, 41(1-2), 127 - 150.

Nowotny, H., P. Scott, \& M. Gibbons (2001). Re-thinking science: knowledge and the public in an age of uncertainty. Cambridge, UK: Polity.

O'Brien, G., P. O'Keefe, H. Meena, J. Rose, L. Wilson (2008). Climate adaptation from a poverty perspective. Climate Policy, 8(2), 194-201.

Olsson, P., C. Folke, \& F. Berkes (2004). Adaptive comanagement for building resilience in socialecological systems. Stockholm: Beijer International Institute of Ecological Economics.

Olsson, P., L.H. Gunderson, S.R. Carpenter, P. Ryan, L. Lebel, C. Folke, \& C.S. Holling (2006). Shooting the rapids: navigating transitions to adaptive governance of social-ecological systems. Ecology and Society, 11(1).

Osborne, D., \& T. Gaebler (1992). Reinventing government: how the entrepreneurial spirit is transforming the public sector. Reading, Massachusetts: Addison-Wesley.

Ostrom, E. (1990). Governing the commons: the evolution of institutions for collective action. Cambridge; New York: Cambridge University Press. 
Pahl-Wostl, C. (2006). The importance of social learning in restoring the multifunctionality of rivers and floodplains. Ecology \& Society, 11(1), 10.

Pahl-Wostl, C. (2007). Transitions towards adaptive management of water facing climate and global change. Water Resources Management, 21(1), 49-62.

Parson, E.A., R.W. Corell, E.J. Barron, V. Burkett, A. Janetos, L. Joyce, T.R. Karl, M.C. MacCracken, J. Melillo, \& M.G. Morgan (2003). Understanding climatic impacts, vulnerabilities, and adaptation in the United States: building a capacity for assessment. Climatic Change, 57(1), 942.

Pielke, R.A. (2007). The honest broker: making sense of science in policy and politics. Cambridge, New York: Cambridge University Press.

Pierre, J. (2000). Debating governance: authority, steering, and democracy. Oxford: Clarendon.

Pierre, J., \& B.G. Peters (2000). Governance, politics, and the state. New York: St. Martin's Press.

Pyke, C.R., B.G. Bierwagen, J. Furlow, J. Gamble, T. Johnson, S. Julius, \& J. West (2007). A decision inventory approach for improving decision support for climate change impact assessment and adaptation. environmental Science \& Policy, 10, 610 - 621.

Raadgever, G.T.T., E. Mostert, N. Kranz, E. Interwies, \& J.G. Timmerman (2008). Assessing Management Regimes in Transboundary River Basins: Do They Support Adaptive Management? Ecology \& Society, 13(1), 14.

Rhodes, R.A.W. (1996). The new governance: governing without government. Political studies., 44(4), 652.

Rhodes, R.A.W. (1997). Understanding governance: policy networks, governance, reflexivity and accountability. Buckingham: Open University Press.

Ribot, J.C., A.R. Magalhaes, \& S.S. Panagides (1996). Climate variability, climate change, and social vulnerability in the semi-arid tropics. Cambridge; New York, NY, USA.

Rotmans, J., R. Kemp, \& M. Van Asselt (2001). more evolution than revolution: transition management in public policy. Foresight, 3(1), 15-31.

Ruitenbeek, H.J., \& C.M. Cartier (2001). The invisible wand: adaptive co-management as an emergent strategy in complex bio-economic systems. Bogor, Indonesia: Center for International Forestry Research..

Runhaar, H., P.P.J. Driessen, L. Soer (2009). Sustainable urban development and the challenge of policy integration; an assessment of planning tools for integrating spatial and environmental planning. Environment \& Planning B, March (forthcoming).

Salamon, D. (1981). On dynamic observation and state feedback for time delay systems. Bremen: University Press.

Salamon, L.M., \& O.V. Elliott (2002). The tools of government: A guide to the new governance. Oxford; New York: Oxford University Press.

Scharpf, F.W. (1997). Games real actors play: actor-centered institutionalism in policy research. Boulder, Colo.: Westview Press.

Scholz, R.W. (2000). Mutual learning sessions. Zurich: Haffmanns.

Scholz, R.W., \& O. Tietje (2002). Embedded case study methods: integrating quantitative and qualitative knowledge. Thousand Oaks, California: Sage Publications.

Smit, B., \& O. Pilifosofa (2001). Adaptation to climate change in the context of sustainable development and equity. In O. F. C. J.J. McCarthy, N.A. Learly, D.J. Dokken \& S. White (Eds.) (Ed.), Climate change 2001: impacts, adaptation, and vulnerability (pp. pp. 876-912). New York

Spit, T.H.M., \& P.R. Zoete (2006). Ruimtelijke ordening in Nederland: een wetenschappelijke introductie in het vakgebied. The Hague: Sdu. 
Stehr, N., \& H. Von Storch (2005). Introduction to papers on mitigation and adaptation strategies for climate change: Protecting nature from society or protecting society from nature? .

Environmental Science and Policy, 8(6), 537-540.

Swart, R., G.R. Biesbroek, S. Binnerup, T.R. Carter, C. Cowan, T. Henrichs, S. Loquen, H. Mela, M.D. Morecroft, M. Reese, D. Rey (2009). Europe adapts to climate change: comparing national adaptation strategies, PEER report no. 1, Partnership for European Environmental Research, Helsinki.

Swart, R., F. Raes (2007). Making integration of adaptation and mitigation work: mainstreaming into sustainable development policies? Climate Policy, 7(4), 288-303.

Termeer, C.J.A.M. (2009). Barriers to new modes of horizontal governance: A sensemaking perspective. Public Management Review, (accepted).

Termeer, C.J.A.M., \& B. Kessener (2007). Revitalizing stagnated policy processes: Using the configuration approach for research and interventions. Journal of Applied Behavioral Science, 43, 256-272.

Thompskins, E.L., \& W.N. Adger (2004). Does Adaptive Management of Natural Resources Enhance Resilience to Climate Change? Ecology and Society, 9(2), 10.

Thompson Klein, J. (2001). Transdisciplinarity: joint problem solving among science, technology, and society: an effective way for managing complexity. Basel: Birkhauser Verlag.

TNO. (2008). Economische effecten van klimaatverandering. Delft: TNO.

Tol, R.S. (2005). Adaptation and mitigation: trade-offs in substance and methods. Environmental Science and Policy, 8(6), 572-578.

Tompkins, E. L., W.N. Adger (2004). Does adaptive management of natural resources enhance resilience to climate change? Ecology and Society, 9(2), 10.

True, J.L., B.D. Jones, \& F.R. Baumgartner (2007). Punctuated equilibrium theory: explaining stability and change in policymaking. In P. A. Sabatier (Ed.), Theories of the policy process (pp. 155187). Colorado: Westview Press.

Van den Besselaar, P. (2006). Science system assessment: onderzoeksprogramma 2005-2008. Den Haag: Rathenau.

Van der Knaap, P., C.J.A.M. Termeer, M.J.W. van Twist(eds.) (2004). Trajectmanagement; Beschouwingen over beleidsdynamiek en organisatieverandering. Lemma, Utrecht.

Van der Sluijs, J. (2005). Uncertainty as a monster in the science-policy interface: four coping strategies. Water Science and Technology: a Journal of the International Association on Water Pollution Research, 52(6), 87-92.

Van der Sluijs, J. P. (1997). Anchoring amid uncertainty: on the management of uncertainties in risk assessment of anthropogenic climate change : houvast zoeken in onzekerheid: het omgaan met onzekerheden in risicoanalyse van klimaatverandering door menselijk handelen.

Rijksuniversiteit Utrecht.

Van Dinteren, J. (2008). Bedrijventerreinen als speelveld. Oratie Faculteit Ruimtelijke Wetenschappen, Rijksuniversiteit Groningen.

Vasbinder, W., \& S. Kern (2005). Bouwstenen voor Science System Assessment, Rathenau Instituut. Den Haag: Rathenau Instituut.

Verschuren, P., \& H. Doorewaard (1999). Designing a research project. Utrecht: Lemma.

Voss, J.P. (2007). Innovation processes in governance: the development of 'emissions trading' as a new policy instrument. Science and Public Policy, 34(5), 329 - 343.

Walker, B., S. Carpenter, J. Anderies, N. Abel, G. Cumming, M. Janssen, L. Lebel, J. Norberg, G. Peterson, \& R. Pritchard (2002). Resilience management in socio-ecological systems: a working hypothesis for a participatory approach. Conservation Ecology, 6(1).

Weick, K.E., \& K.M. Sutcliffe (2001). Managing the unexpected: assuring high performance in an age of complexity. San Francisco: Jossey-Bass. 
Wellstead, A.M., R.C. Stedman (2007). Coordinating future adaptation policies across Canadian natural resources. Climate Policy, 7(1), 29-45.

Wilbanks, T.J., S.M. Kane, P.N. Leiby, R.D. Perlack, C., J.F. Settle Shogren, \& J.B. Smith (2003). Possible responses to global climate change: Integrating mitigation and adaptation. Environment, 45, 28-39.

Wildavsky, A. (1988). The new politics of the budgetary process. Foresman: Glenview.

Wildemeersch, D., T. Jansen, J. Vandenabeele, \& M. Jans (1998). Social learning: a new perspective on learning in participatory systems. Studies in Continuing Education, 20(2), 251-265.

Wilson, E. (2006). Developing UK spatial planning policy to respond to climate change. Journal of Environmental Policy \& Planning, 8, no. 1, pp. 9-25.

Wynne, B. (1992). Uncertainty and environmental learning: reconceiving science and policy in the preventive paradigm. Global Environmental Change, 2(2), 111 - 127. 


\section{Appendix 1A: Journals Environmental Studies, ISI Ranking on impact factor}

Annual Review of Environment and Resources

Global Environmental Change

Energy policy

Environment and Planning D - Society \& Space

Regional Studies

Harvard Environmental Law Review

Environmental and planning $A$

International Regional Science review

Landscape and urban planning

Energy Journal

Ecological Economics

Journal of Environmental Economics and Management

Transportation Research Part D-Transport and Environment

Environment

Urban studies

Human Ecology

Environment \& Resource Economics

Land use policy

Journal of Environmental Psychology

Marine Policy

Society and Natural Resources

Resource and Energy Economics

Land Economics

Cultural Geographies

Environmental Impact Assessment Review

Environmental History

Population and Environment

Tourism Management

Regional Science and Urban Economics

Environment and Behavior

Journal of Regional Science

Environmental Politics

Environmental Values

Environment and Planning B - Planning \& Design

Environment and Urbanization

Natural Resources Forum

Climate Policy

Ecology Law Quarterly

Progress in Planning

Environment and Development Economics

Papers in Regional Science

Housing Studies

Organization \& Environment

Environment and Planning C - Government and Policy

Annals of Regional Science

Habitat International

GAIA-Ecological Perspectives for Science and Society

European Urban and Regional Studies

Resources Policy

Journal of Architectural and Planning Research

Environmental Ethics

Natural Resources Journal 


\title{
Appendix 1B: Journals Planning and Development, ISI ranking on impact factor
}

\author{
Research Policy \\ Journal of the American Planning Association \\ World Bank Research Observer \\ Long Range Planning \\ World Development \\ Journal of Planning Literature \\ Journal of Rural Studies \\ International Journal of Urban and Regional Research \\ World Bank Economic Review \\ Sustainable Development \\ Society \& Natural Resources \\ Development and Change \\ Technological Forecasting and Social Change \\ Economic Development and Cultural Change \\ Journal of Planning Education and Research \\ Futures \\ 17) Growth and Change \\ Journal of Regional Science \\ European Planning Studies \\ Journal of Development Studies \\ Disasters \\ Progress in Planning \\ Public Administration and Development \\ Third World Quarterly \\ Studies in Comparative International Development \\ Policy Sciences \\ Review of Development Economics \\ Housing Policy Debate \\ Economic Development Quarterly \\ Social Policy \& Administration \\ Habitat International \\ Local Government Studies \\ 33) Journal of Forecasting \\ 34) IDS Bulletin-Institute of Development Studies \\ 35) Developing Economies \\ 36) African Development Review-Revue Africaine de Developpment \\ 37) International Development Planning Review \\ 38) Canadian Journal of Development Studies-Revue Canadienne D Etudes Du \\ 39) Regional studies \\ 40) Journal of the American Association \\ 41) Journal for Planning and Research \\ 42) Landscape and Urban Planning \\ 43) Environment and Planning A: urban and regional research \\ 44) Environment and Planning D-Society \& Space \\ 45) International Journal of Urban and Regional Research \\ 46) Journal of Environmental Planning and Management \\ 47) Land Use Policy \\ 48) Landscape Ecology \\ 49) Landscape Research \\ 50) Planning Theory \\ 51) Planning Theory and Practice \\ 52) Town Planning Review \\ 53) Transport Reviews \\ 54) Built environment \\ 55) International Planning Studies \\ 56) Journal of Environmental Policy and Planning \\ 57) Planning Practice and Research \\ 58) Journal of Environmental Planning and Management
}


59) Planning Perspective

60) Environment Development and Sustainability

61) Cities 


\section{Appendix 1C: Journals Public Administration, ISI ranking on impact factor}

Journal of Public Administration Research and Theory

Journal of Policy Analysis and management

Public Administration Review

Journal of European Public Policy

Journal of Social Policy

Philosophy \& Public Affairs

Public Administration

Policy and Politics

Governance - An International journal of Policy and Administration

Administration \& Society

Public Money \& Management

American Review of Public Administration

Climate Policy

Public Administration and Development

Policy Sciences

Environment and Planning $\mathrm{C}$ - Government and Policy

Contemporary Economic Policy

Policy Studies Journal

Public Interest

Local Government Studies

Public Management Review

International Review of Administrative Sciences

Australian Journal of Public Administration

Administration in Social Work

Public Personnel Management

Canadian Public Policy - Analyse de Politiques

Canadian Public Administration - Administration Publique du Canada 


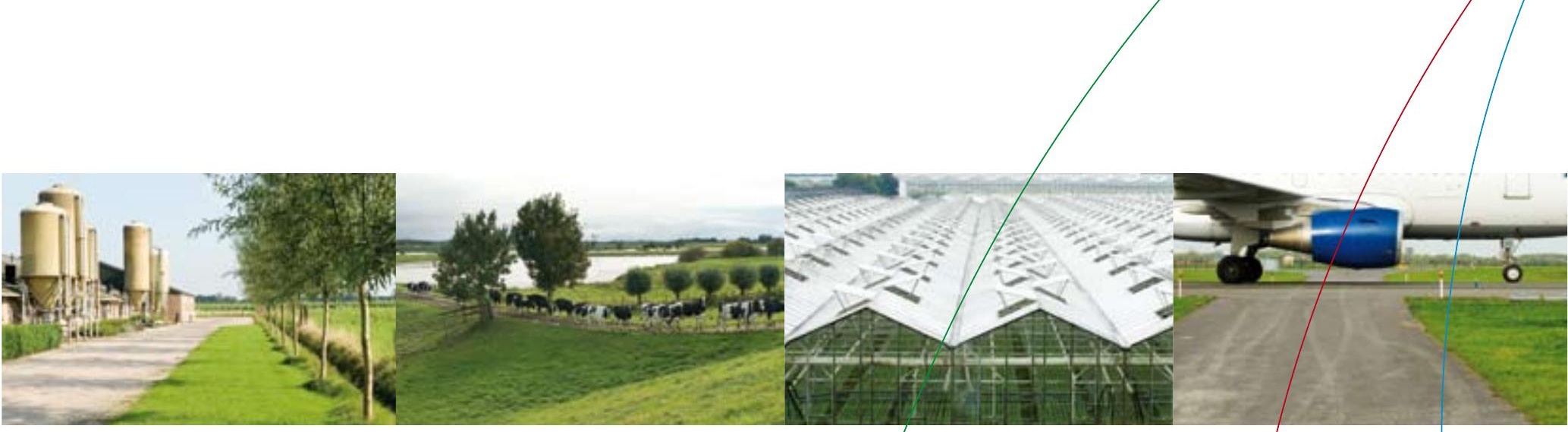

To develop the scientific and applied knowledge required for climate-proofing the Netherlands and to create a sustainable knowledge infrastructure for managing climate change

Contact information

Knowledge for Climate Programme Office Secretariat:

c/o Utrecht University

P.O. Box 80115

3508 TC Utrecht

The Netherlands

T +31883357881

E office@kennisvoorklimaat.nl

Public Relations:

c/o Alterra (Wageningen UR)

P.O. Box 47

6700 AA Wageningen

The Netherlands

T +31317486540

E info@kennisvoorklimaat.nl

www.knowledgeforclimate.org

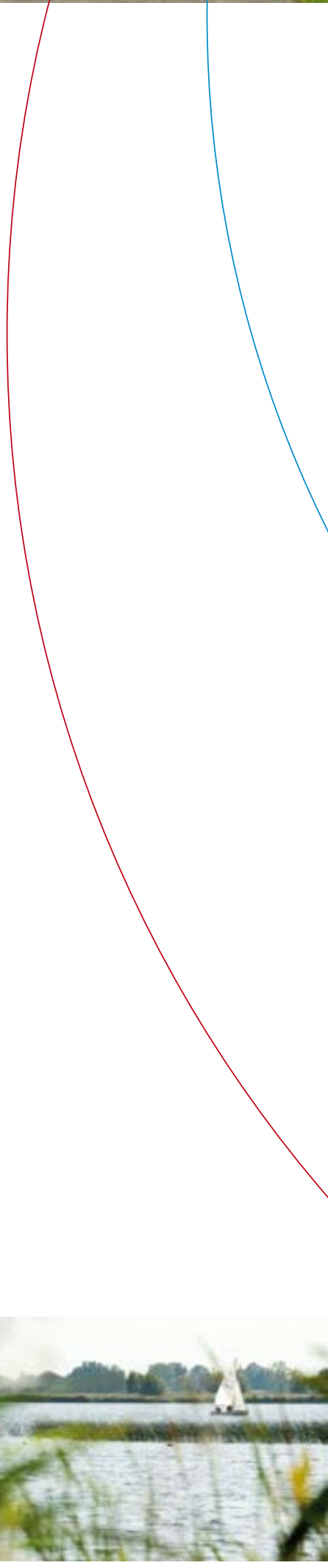

